\title{
The Iron Age in the Mragowo Lake District, Masuria, NE Poland: the Salęt settlement microregion as an example of long-lasting human impact on vegetation
}

\author{
Marta Szal • Mirosława Kupryjanowicz • \\ Mariusz Wyczółkowski • Wojciech Tylmann
}

Received: 27 January 2014/ Accepted: 28 April 2014/Published online: 6 June 2014

(c) The Author(s) 2014. This article is published with open access at Springerlink.com

\begin{abstract}
Pollen, non-pollen palynomorphs, charcoal and geochemical analyses of sediments from Lake Salęt (NE Poland) were used to reconstruct vegetation changes related to the activity of the West Balt tribes during the Iron Age, in the period between the second half of the 7th century $\mathrm{BC}$ and the beginning of the 10th century $\mathrm{AD}$. We distinguished five phases of human impact on environment. Woodland clearing around the studied lake started at the end of the 7th century BC. The most characteristic feature of this area during the whole Iron Age was a very high representation of semi-natural Betula woodlands, which was probably linked to a shifting agriculture. This type of land use lasted for over 1,500 years, until the second half of the 9th century AD. The greatest reduction in Betula woodlands
\end{abstract}

Communicated by M. Latałowa.

Electronic supplementary material The online version of this article (doi:10.1007/s00334-014-0465-z) contains supplementary material, which is available to authorized users.

\section{Szal $(\bowtie) \cdot$ M. Kupryjanowicz}

Institute of Biology, University of Białystok, Świerkowa 20b, 15-950 Białystok, Poland

e-mail: martaszal@op.pl

M. Kupryjanowicz

e-mail: m.kupryjanowicz@uwb.edu.pl

M. Wyczółkowski

Wojciech Kętrzyński Museum, Plac Zamkowy 1,

11-400 Kętrzyn, Poland

e-mail: mw@muzeum.ketrzyn.pl

\section{W. Tylmann}

Department of Geomorphology and Quaternary Geology, Institute of Geography, University of Gdańsk, Bażyńskiego 4, 80-952 Gdańsk, Poland

e-mail: geowt@univ.gda.pl took place between cal. years 650 and 450 BC. Its regeneration took place after ca. AD 830 when human activity decreased.

Keywords Pollen - Microcharcoal $\cdot$ NPPs .

Geochemistry · NE Poland · Human impact · Shifting agriculture $\cdot$ Iron Age $\cdot$ West Balts

\section{Introduction}

In Europe, one of the most significant changes in the humanenvironment relationship took place during the Iron Age. However, it must be noted that this period is defined here in several ways (e.g. Thurston 2009). The chronological system of the Iron Age in north-eastern Poland is slightly different to that adopted for the cultural situation in both Central and Northern Europe and is based on the Tischler system of relative chronology (Tischler 1885; Tischler and Kemke 1902). In the modern system of chronology, the division of the Iron Age in this part of Poland into the early Iron Age (mid 6th century BC to ca. AD 20; Hoffmann 2000), the Roman Period (ca. AD 20 to mid 4th century AD; Okulicz 1973) and the Migration Period (second half of the 4th to end of the 7th century AD; Godłowski 1974; Nowakowski 1996; Bitner-Wróblewska 2010) was proposed.

Technological advances, particularly the development of ferrous metallurgy and the wide dissemination of tools made from this metal, as well as the emergence of new types of these, meant that man effectively increased his capacity to master and transform the environment. This was primarily vegetation, which in many places underwent a remarkable transformation through the destruction or thinning of some woodlands and the formation of large deforested areas, which were used as fields, pastures and 
meadows, or were left as wasteland (e.g. Kreuz and Schäfer 2008; Giesecke et al. 2014). A broad range of changes resulted from extensive forms of economic activity, particularly related to domestic animal husbandry and slashand-burn type agriculture (e.g. Alenius et al. 2008; Grabowski 2011). Intensive construction works utilizing large quantities of wood commonly used in all areas of construction were not without significance. Wood was also one of the most important fuel materials, and was used in a number of specialized branches of non-agricultural production, such as iron smelting, the distillation of wood tar and coal tar etc. (e.g. Collis 1984).

A special feature of the Iron Age in the north-eastern part of Central Europe was the spread of Balts cultures in the south-eastern coastal zone of the Baltic Sea. They were diversified into a number of local groups with ranges coincident with the borders of geographical sub-regions (Okulicz 1976). Starting from 7th century BC, the westsouthern part of the Balt zone was occupied by the West Balt Barrow culture (e.g. Okulicz 1970, 1989; Hoffmann 2000). The population of this culture maintained long distance links with the peoples of the woodland zone of Eastern Europe, the Baltic seacoast and areas in southeastern Europe (Hoffmann 2000). They were also engaged in trading amber, which they supplied to the Celts, who at this time were spread over much of western, central and southern Europe (Nowakowski 2004).

The subsequent West Balt culture (Bogaczewo Culture) developed during the period of the 1st to 4th century AD. The state of knowledge of the settlement pattern of this culture in the Masurian Lakeland is insufficient, and is based on advanced studies of settlement microregions carried out in only two areas. These were in the Mragowo Lake District (a settlement microregion around Lake Salęt) and in the Great Masurian Lake District (a settlement microregion on the north shore of the palaeolake Wons and settlement microregion Staświny) (Karczewski 2012). In the period from around the second until the 4th century AD, long-distance links were maintained with other regions of the Baltic Sea, and also with the territory lying in the west and south occupied by the Germanic tribes of Vandals and Goths (identified with the Przeworsk culture and the Wielbark culture, respectively). An important element of these contacts was involvement in trade connected with the Amber Road, which ran from the Roman Empire to the Baltic seacoast (Nowakowski 1995; Nowakowski 2004; Nowakiewicz and Nowakiewicz-Rzeszotarska 2012). At the end of the fourth and at the beginning of the 5th century (early Migration Period), a demographic crisis in the territory of the Bogaczewo culture was registered (e.g. Szymański 2005; Bitner-Wróblewska 2010). However, the settlement in the Mragowo Lake District, despite its partial decline, survived, and from ca. AD 450 revived to flourish anew. A new cultural unit with a mixed Balt-Germanic character, the Olsztyn Group, is described (Kowalski 2000; Bitner-Wróblewska 2010). This is because during the Late Migration Period in Masuria we see an accumulation, not encountered elsewhere in this part of Europe, of elements of interregional Germanic culture. The decline of the Olsztyn Group, dated to the 7th or even 8th century (Bitner-Wróblewska 2008; Kowalski 2000), is one of the greatest riddles of Masuria's archaeological past. An unprecedented rate of change (starting at the end of the 7th century, during the lifetime of one, or at most, two generations) in conjunction with a lack of traces of destruction, points to the existence of quite special and not fully understood causes which led to an abrupt break in a Balts settlement tradition of nearly 13 centuries duration (Okulicz 1973).

Palaeoecological investigations, particularly pollen analysis, have greatly contributed to our knowledge of prehistoric environments and the manner in which human activity affected them (e.g. Behre 1988; Latałowa 1999; Beug 2011). The interactions between human society and environmental change can be deduced preferably from pollen records in combination with the study of non-pollen palynomorphs (NPPs), especially fungal and algal spores, which have in recent decades substantially complemented palaeoecological research (e.g. van Geel et al. 1994, 2003; van Geel and Aptroot 2006; Święta-Musznicka et al. 2013).

In north-eastern Poland the state of multidisciplinary researches on man/environment relationships in the Iron Age is very limited (Karczewski 2012). In the Masurian Lakeland a direct comparison of archaeological and palaeoecological data is possible only in the case of two settlement microregions from the Great Masurian Lake District: the microregion at the paleolake Wons (e.g. Karczewska and Karczewski 2002; Karczewska et al. 2002; Kupryjanowicz et al. 2013) and the Staświny microregion (e.g. Wacnik 2009; Madeja et al. 2010; Karczewski 2011; Wacnik et al. 2012; Wacnik and Karczewski 2013). Recently, multidisciplinary palaeoenvironmental investigations have also been undertaken in the area of Lake Salęt in the Mragowo Lake District, where detailed archaeological excavations have been ongoing for several decades, undertaken by the Institute of Archaeology, University of Warsaw, so there is now a significant accrual of archaeological data available (e.g. Okulicz 1973; Szymański 2003, 2005, 2007; Wróblewski 2006). However, prior to this study no palynological data that describe the past environment and agricultural history of the area have been collected at this site.

The aim of this paper is to present the first results of interdisciplinary palaeoecological research, the main objectives of which were to study the human impact on the environment, and changes in the economy of local groups 
of West Balts that inhabited the area around Lake Salęt during the Iron Age. Good recognition of these processes in the studied microregion will make it possible to formulate generalizations about the functioning of the West Balts settlement within the whole area under their influence.

\section{Study area}

The Mrągowo Lake District (ca. 2,000 $\mathrm{km}^{2}$ ) lies in a large hump between the Great Masurian Lake District to the east, and the Olsztyn Lake District to the west. In terms of geomorphology the region is situated within the reach of the last glaciation formations and forms. The diversified hilly mosaic relief with a large number of lakes is the effect of glacier activity (Kondracki 2011).

The soil cover is strongly differentiated, with a predominance of zonal soils, namely eutric cambisols and podzols. Hydrogenic and semi-hydrogenic soils cover the low lying terrain along rivers and near lakes. The characteristic intrazonal soils of the Mragowo Lake District that also occur in the region of the studied lake are gyttja soils formed from different types of lake sediments. They are often associated with peaty soils in fens (Uggla 1969; Bednarek and Prusinkiewicz 1999; Richling and Ostaszewska 2005).

The climate of the region is among the coldest lowland climates in Poland, with a mean annual temperature of $6.5^{\circ} \mathrm{C}$ (the mean temperature in January is $-4.0^{\circ} \mathrm{C}$; the mean temperature in July is $17.4{ }^{\circ} \mathrm{C}$ ). Mean annual precipitation is $550 \mathrm{~mm}$ with a predominance of summer rainfall (Kożuchowski 2011). The length of the growing season is 206 days, snow cover persists for 98 days on average, and the lakes are ice-covered for 3-4 months (Woś 1999). All these features indicate the transitional character of the climate, resulting from the occurrence of different air masses, both oceanic and continental.

Due to the specific climatic conditions, the vegetation of the studied region also has a transitional character. It is exemplified by the co-occurrence of central European species (e.g. Cladium mariscus, Juncus subnodulosus; Gałka et al. 2014) and north-east European species like Polemonium caeruleum, Nymphaea candida, Nuphar pumila, as well as representing the range limit for numerous plant communities both of boreal (e.g. Sphagno-Piceetum, Querco-Piceetum) and oceanic type (e.g. Galio odoratiFagetum, Luzulo pilosae-Fagetum, Stellario-Carpinetum, Fago-Quercetum) (Matuszkiewicz 2005). Also the eastern limits of Fagus sylvatica and Acer pseudoplatanus (Zajac and Zajac 2001), the western limit of Quercus petraea and the southern limit of Salix lapponum (Szafer and Zarzycki 1977) natural ranges run through this area.

The potential natural vegetation of the Mragowo Lake District would be formed mainly by the subboreal type of

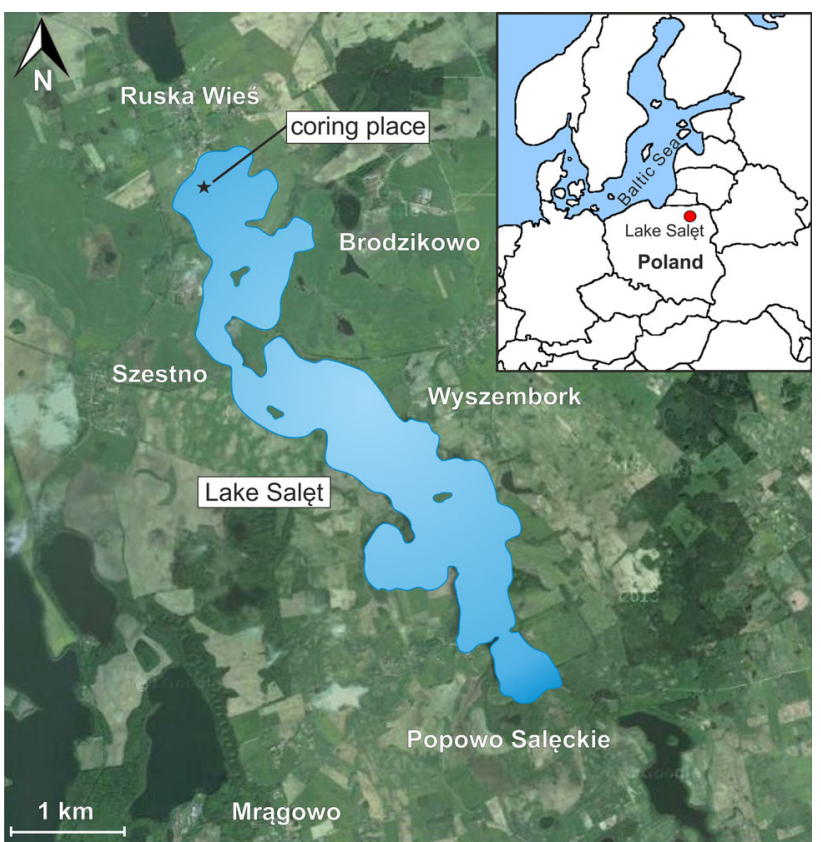

Fig. 1 Location of Lake Salęt and coring site $\left(53^{\circ} 56^{\prime} 22.09^{\prime \prime} \mathrm{N}\right.$, $\left.21^{\circ} 19^{\prime} 20.19^{\prime \prime} \mathrm{E}\right)$. Produced using Google Maps

Carpinus woodland (Tilio-Carpinetum) and by mixed Quercus-Pinus woodland (Querco-Pinetum). The southern part of the mezoregion lies within the range of subboreal Pinus woodland (Peucedano-Pinetum). Locally, there would also develop azonal communities of middle-European wet Alnus woodlands (Carici elongatae-Alnetum), riparian woodlands (Fraxino-Alnetum) and bog pine woodlands (Vaccinio uliginosi-Pinetum) (Matuszkiewicz 2008). There is a great discrepancy between the real and potential vegetation in this terrain-woodlands occur mainly in the southern part of the region and are dominated by Pinus and mixed Pinus woodlands prevailing on sandy soils, while the area of Quercus-Carpinus woodlands is very limited due to heavy deforestation and the exploitation of terrain as plough-land and meadows or pastures.

\section{Site description}

Lake Salęt $\left(53^{\circ} 56^{\prime} 22.09^{\prime \prime} \mathrm{N}, 21^{\circ} 19^{\prime} 20.19^{\prime \prime} \mathrm{E}\right)$ is a eutrophic, meromictic lake with a surface area of 327.7 ha. It is situated in the central part of the Mraggowo Lake District (Fig. 1).

The lake is of glacial origin (Kondracki 2011). It is situated in a depression surrounded by morainic hills. Steep escarpments, over $10 \mathrm{~m}$ high, slope down to the water surface on both the eastern and western lakesides; the northern and southern slopes are gentler. The lake is divided into two parts: the smaller, northern part is named Lake Salęt Mały, and the larger southern is Salęt Wielki (Fig. 1). The lake attains a maximum water depth of ca. 


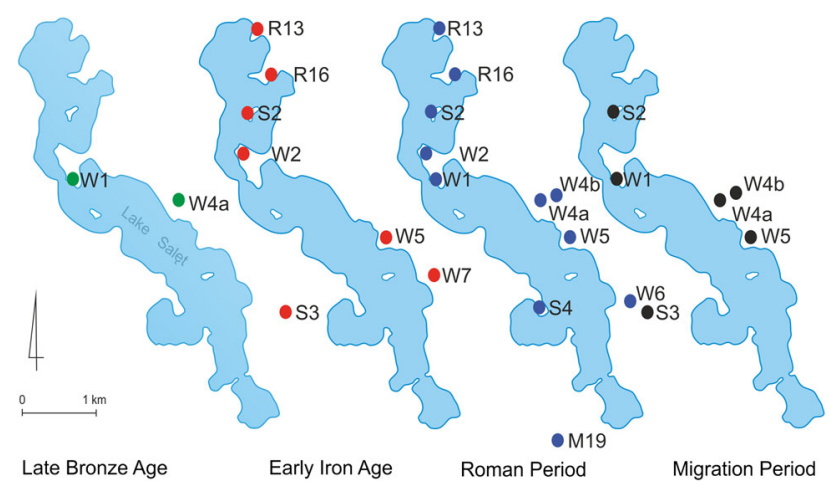

Fig. 2 Archaeological sites around Lake Salęt: M19-Muntowo, site XIX; R13-Ruska Wieś, site XIII; R16—Ruska Wieś, site XVI; S2Szestno, site II; S3-Szestno, site III; S4-Szestno, site IV; W1Wyszembork, site I; W2-Wyszembork, site II; W4a-Wyszembork, site IVa; W4b-Wyszembork, site IVb; W5-Wyszembork, site V; W6-Wyszembork, site VI; W7-Wyszembork, site VII

$17.2 \mathrm{~m}$ in the northern part; its average depth is $4.9 \mathrm{~m}$ (Jańczak 1999). It is fed by one stream, and in addition to the surface run-off probably also by the inflow of shallow underground waters from the moraine upland.

The vegetation surrounding Lake Salęt is devoid of woodland and is strongly affected by human impact. Woodlands cover only ca. $10 \%$ of the area. A considerable area is taken by grasslands: meadows and pastures cover ca. $30 \%$, and agriculturally used ground covers ca. $60 \%$. Up to a distance of $500 \mathrm{~m}$ from the lakeshore the terrain is overgrown by herbaceous vegetation, with scattered trees occurring only near buildings, along roads, streams, and at the lake shore.

Archaeological chronology of the Lake Salęt settlement microregion

In the late Bronze Age a settlement, which was connected with the Masuria-Warmia Group of the Lusatian culture, appeared on the territory around Lake Salęt (Okulicz 1981) and lasted until the beginning of the Iron Age. Its traces were discovered in Wyszembork, sites I and IVa (Nowakowska 2004; Szymański 2005) (Fig. 2).

Three settlement phases of the Iron Age were distinguished. The first (early Iron Age) corresponds to the West Balt Barrow culture. The settlement remnants of this culture are relatively numerous in the microregion: seven settlements have been identified: Wyszembork, sites II, V and VII; Szestno, sites II and III; Ruska Wieś, sites XIII and XVI (Gładki 2007; Szymański 2005). The second settlement phase is dated to the 1 st to 4 th century $\mathrm{AD}$ (Roman Period) and is correlated to the Galindai tribes, connected with the Bogaczewo culture (e.g. Nowakowski 1995, Nowakowski 2004). Nine settlements and a cemetery at Wyszembork site IVa dated to this period have been described (Szymański 2005). The third settlement phase corresponds to the Migration Period (Olsztyn Group), represented by five settlements and a cemetery at Wyszembork, site IVa (Szymański 2005). In about the 7th century AD the gradual collapse of the settlement and the depopulation of this area probably took place (Szymański 2005). However, Białuński (1999) suggests that in some regions of the Masurian Lakeland settlements were scattered but still persisted.

\section{Materials and methods}

\section{Coring}

In the winter of 2010 a sediment core was recovered from the frozen surface of Lake Salęt with the use of Więckowski's piston corer and a Kajak gravity corer. Coring was performed close to the deepest part of the lake (at a water depth of $15 \mathrm{~m}$ ), where the deposits had the greatest thickness, equal to $15.7 \mathrm{~m}$ (Fig. 1). The present paper deals only with the section 7.0-3.8 $\mathrm{m}$ of the profile, which accumulated from ca. $750 \mathrm{BC}$ to $\mathrm{AD} 920$. Calcareous gyttja, rich in organic matter, and relatively poor in sand, clay and silt forms this part of the studied core.

\section{Dating}

AMS radiocarbon dating of seven samples from the Salęt profile was performed in the Gliwice Absolute Dating Methods Centre (ESM Table 1). Only three dates deal directly with the part of the core that is discussed in this study. The sediments contained no macroremains of terrestrial plants, and therefore it was necessary to use plant pollen as the only organic matter less contaminated than gyttja. The isolation of pollen concentrates from the sediment was performed by the removal of calcium carbonate using $38 \% \mathrm{HCl}$, and humic acids using $10 \% \mathrm{KOH}$. In every case $2-4 \mathrm{~cm}^{3}$ of sediment was used for this purpose. The resulting conventional radiocarbon dates were calibrated against the IntCal09 calibration curve (Reimer et al. 2009) using the OxCal Version 4.1.7 program (Bronk Ramsey 2010).

Short-lived radionuclides ${ }^{210} \mathrm{~Pb}$ were measured in the uppermost $30 \mathrm{~cm}$. Measurements were carried out in the Institute of Geological Sciences of the Polish Academy of Sciences in Warsaw.

The ${ }^{14} \mathrm{C}$ and ${ }^{210} \mathrm{~Pb}$ dates were used for construction of an age-depth model for the analysed profile (Fig. 3). This model was built by means of the polynomial second-degree 


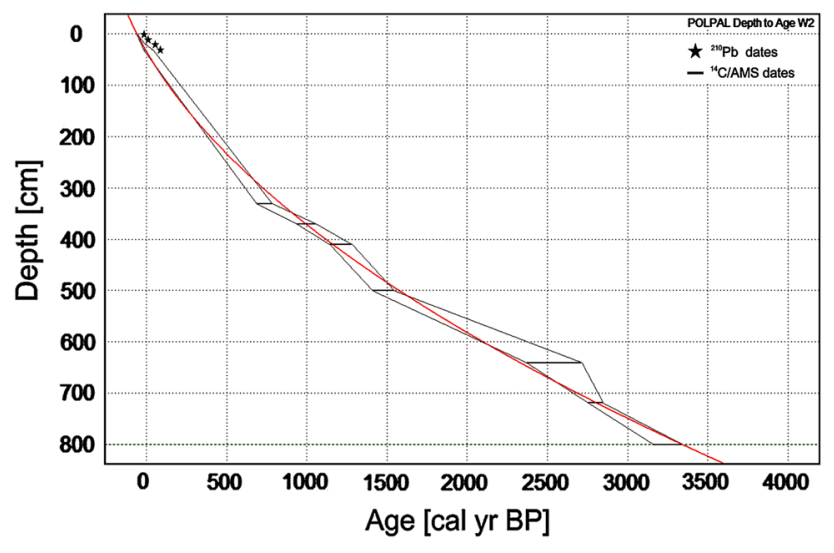

Fig. 3 Age-depth model of the Salęt profile based on AMS ${ }^{14} \mathrm{C}$ dates and ${ }^{210} \mathrm{~Pb}$ dates

curve fitting in the POLPAL program (Nalepka and Walanus 2003; Walanus and Nalepka 2004).

Pollen, NPPs and charcoal particles

Samples of $1 \mathrm{~cm}^{3}$ were prepared using the standard procedure of Erdtman's acetolysis (Berglund and Ralska-Jasiewiczowa 1986). Depending on the content of mineral matter the samples were treated with a heavy liquid $\left(\mathrm{CdI}_{2}+\mathrm{KI}\right)$. Lycopodium tablets were added to each sample to enable quantitative analysis of microfossil concentration (Stockmarr 1971). Palynological and microcharcoal analysis was performed on 43 samples from the studied part of the Salęt profile. The density of the investigated samples differs in the lower and upper part of the profile (every $10 \mathrm{~cm}$ at depth $470-700 \mathrm{~cm}$ and every $5 \mathrm{~cm}$ at depth $380-470 \mathrm{~cm}$ respectively) and hence the precision of the information obtained also differs - an average interval of 52 years in the lower and 23 years in the upper part of the profile.

Pollen analysis was carried out with an Olympus BX43 light microscope with a magnification of $600 \times$; a larger magnification was used to identify problematic and small palynomorphs. For taxonomical identification pollen keys (e.g. Beug 2004) and the reference collection of modern pollen slides were used. More than 1,000 terrestrial pollen grains were counted and identified in each sample. NPPs were counted along with the pollen. NPPs were identified according to van Geel (1978, 2001), Bell (1983), Jankovská and Komárek (2000), van Geel et al. (2003), Turton and McAndrews (2006) and van Geel and Aptroot (2006). Names of NPP taxa include a three letter code "HdV" for the Hugo de Vries Laboratory of the University of Amsterdam, The Netherlands, where the relevant NPPs were identified for the first time.
The microcharcoal particles were counted in the pollen slides and grouped into four size classes: 10-30, 30-70, $70-100$ and $>100 \mu \mathrm{m}$. According to Rull (2009) the larger particles better reflect the incidence of local fires, whereas the smaller particles are more indicative of regional fires. Particles $<10 \mu \mathrm{m}$ were ignored, as they cannot be safely identified (Blackford 2000). Charcoal particles were identified with a light microscope at $400 \times$ magnification. Charcoal selection was restricted to fragments that were black, completely opaque and angular (Swain1973; Clark 1988).

Calculations and presentation of palynological and microcharcoal data were performed with POLPAL for Windows (Nalepka and Walanus 2003). The AP + NAP sum was used for percentage calculations, both in the pollen and the NPP diagram. The pollen diagram was stratigraphically ordered and zoned with constrained cluster analysis (CONISS) and divided into local pollen assemblage zones (LPAZ), which were named according to the specific composition of pollen spectra. The human impact groups follow Behre (1981), Berglund and Ralska-Jasiewiczowa (1986) and Gaillard and Berglund (1988).

\section{Geochemical analyses}

All sediment core sections were scanned to detect major and trace elements with an ITRAX XRF-core scanner (COX Analytical Systems) at the GEOPOLAR laboratory, University of Bremen. Sections were scanned with a Motube with a step size of $5 \mathrm{~mm}$ and a count time of $10 \mathrm{~s}$. Tube settings were kept constant for all sections using a voltage of $30 \mathrm{kV}$ and a current of $20 \mathrm{~mA}$. Element data produced by the scanner are semi-quantitative and are expressed as total counts, i.e. integrated peak area. Peak area counts of elements were normalized by coherent radiation (i.e. scatter of the primary $\mathrm{X}$-ray radiation), which should reduce the sediment matrix effect (Croudace et al. 2006).

\section{Results}

Palynological data

According to the pollen data for the full profile (M. Szal unpubl. data), the pollen diagram presented in this paper includes only one pollen zone, S-6 Carpinus-BetulaQuercus. It was divided into six subzones, five of them are described here (Fig. 4; ESM Table 2). They reflect five human impact phases covering the period between ca. 750 $\mathrm{BC}$ and $\mathrm{AD} 920$. 


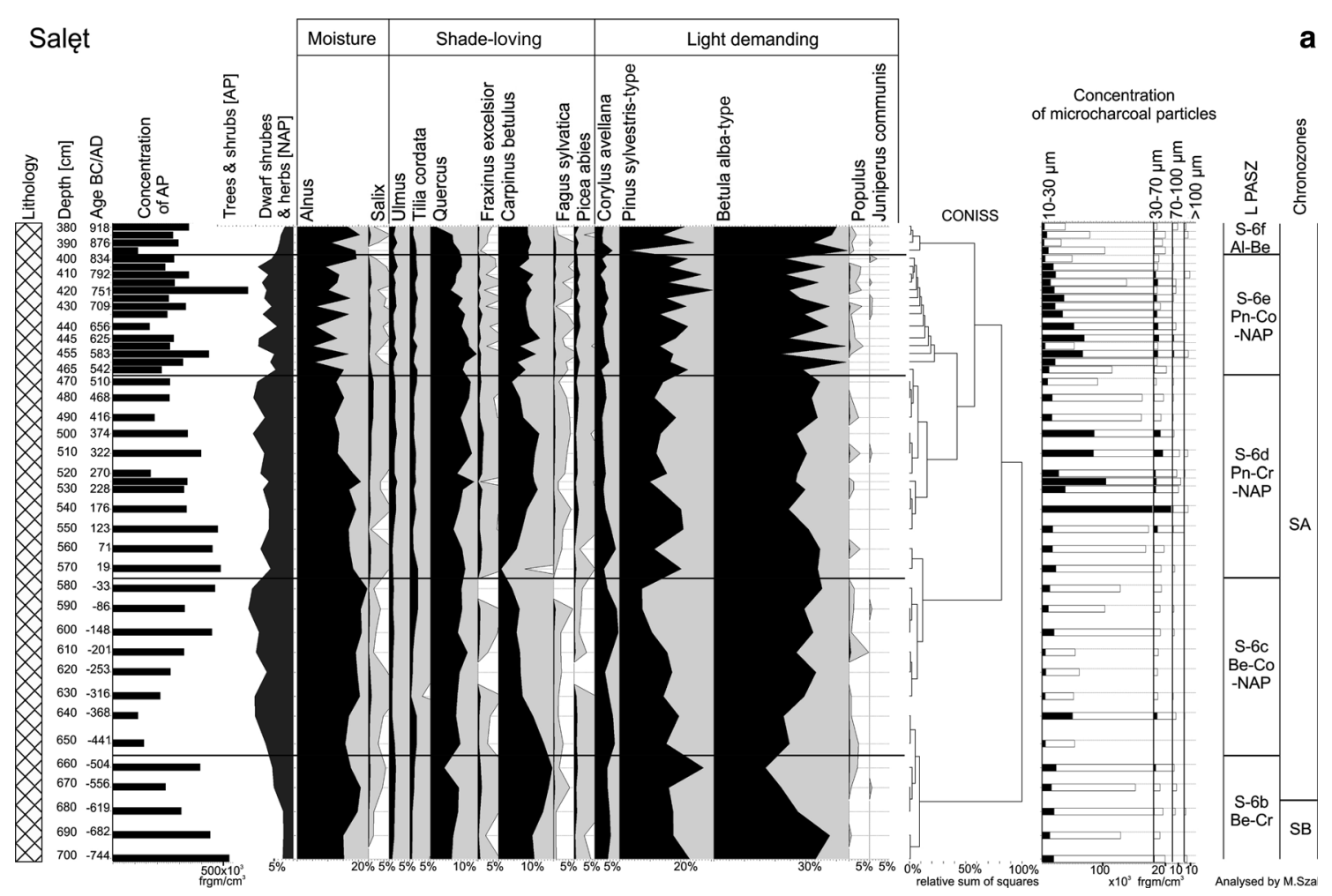

Fig. 4 a Pollen percentage diagram with selected important woody taxa, AP concentration and charcoal record from the Salęt core, lithology: grey-brown calcareous-detritus gyttja, b pollen (selected important herb taxa) and NPPs percentage diagram showing the

Phase 1: ca. 750-450 BC, end of the Bronze to beginning of the early Iron Age (Betula-Carpinus LPASZ, $655-700 \mathrm{~cm}$ )

Vegetation in the vicinity of Lake Salęt at the transition from the Bronze to the Iron Age can be reconstructed on the basis of the pollen record contained in the BetulaCarpinus local subzone (Fig. 4). It shows that the Betula woodlands played a dominant role in the landscape of this period (Fig. 4a). They were probably secondary semi-natural communities which formed in habitats transformed by exploitation during earlier settlement stages. Carpinus woodlands developed intensively, which is documented by relatively high values of Carpinus betulus pollen. Large areas were occupied by Quercus stands. There were Pinus and different mixed woodlands Pinus-Quercus and PinusBetula. Alnus grew on wetland habitats in the surroundings of the lakes and on the outskirts of river valleys. A relatively small area was occupied by Ulmus, Tilia, Fraxinus and Picea. Other trees were rather sporadic.

The start of continuous pollen curves of a few human activity indicators (e.g. Cerealia-type, Plantago lanceolata and Rumex acetosa-type) and an increase in the frequency of several others (e.g. Poaceae, Cyperaceae and Artemisia), document the appearance of anthropogenic communities human impact on local vegetation and its correlation with local settlement history; archaeological data: a local context, b regional context. (Color figure online)

fields, meadows, pastures and ruderal associations-at the end of this phase, after ca. 550 вс (Fig. 4b). These changes probably reflected the first stage of a settlement of the West Balt Barrow culture. They might also be connected with the terminal phase of the Lusatian settlement, which was recorded in numerous pollen diagrams from the Masurian Lake District (e.g. Ralska-Jasiewiczowa and Latałowa 1996, Wacnik et al. 2012).

Phase 2: ca. 450-1 BC, early Iron Age (Betula-CorylusNAP LPASZ, 575-655 cm)

Rather high pollen percentages of trees (ca. $90 \%$ ) and low ones of herbs indicate a forested landscape. However, a decrease in the pollen values of Carpinus betulus, Tilia cordata, Ulmus and Picea abies, coinciding with increasing frequencies of pioneers (Betula and Corylus avellana) and light-demanding (Populus) taxa, suggests a progressive opening of the vegetation. Cannabis/Humulus-type pollen most probably indicates that Humulus lupulus grew in this area as a native plant.

The rise in frequency of pollen indicators of ruderal communities (especially Artemisia and Chenopodiaceae), meadow and pasture (mainly Poaceae, Cyperaceae, Plantago lanceolata, Rumex acetosa-type and Apiaceae), 


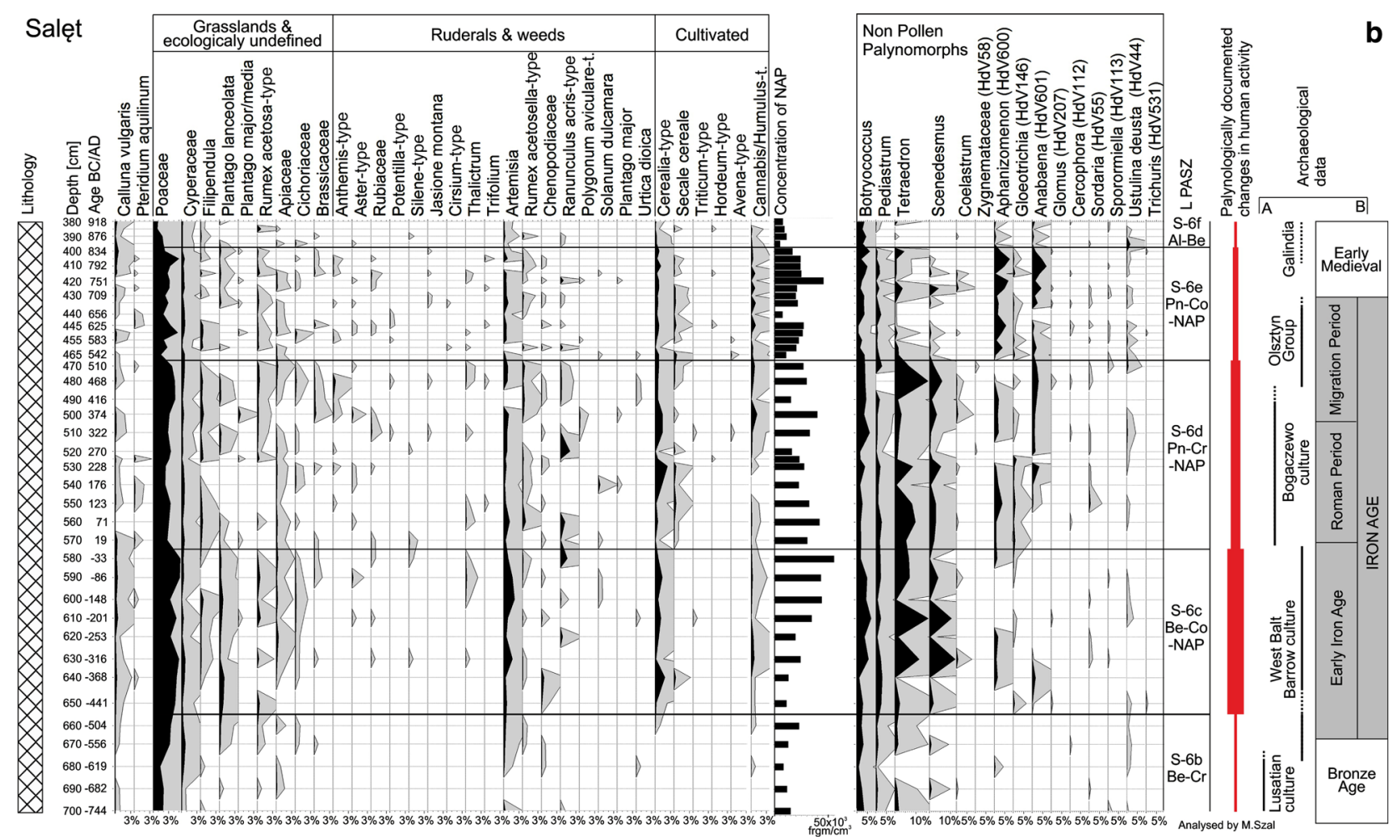

Fig. 4 continued

accompanied by the occurrence of Pteridium aquilinum spores, shows that the surroundings of Lake Salet have been to some extent influenced by man. One apparent sign of human impact is the appearance of cereal fields (clear peak in Cerealia-type and single pollen grains of Triticumtype and Secale cereale).

The drop in the Picea abies pollen curve, concurrent with the slight increase in Artemisia, Plantago lanceolata, Chenopodiaceae pollen and charcoal particles, obviously resulted from further human activities associated with the settlement of the West Balt Barrow culture.

The occurrence of Glomus, though in low frequencies, is here noteworthy as this is a mycorrhizal fungus commonly associated with the roots of trees and shrubs (van Geel et al. 1989), and when recorded in lake deposits points to soil erosion in the catchment area (Anderson et al. 1984).

The increasing human impact in the catchment area of Lake Salęt, as can be interpreted from the pollen records of human impact indicators, apparently had its effect on the trophic conditions of the water in this lake. Therefore remains of green algae in lake sediments, for example the coenobia of Pediastrum, Botryococcus, Scenedesmus and Tetraedron, as well as cyanobacteria (Aphanizomenon, Gloeotrichia and Anabaena) can play an important role in inferring past lake conditions, and almost all are known to be dominant in more eutrophic systems (cf. Van Geel and Grenfell 1996; Jankovská and Komárek 2000; Medeanic et al. 2003; Zamaloa and Tell 2005; Medeanic 2006). Of these, the most abundant was Tetraedron, classified by Bakker and van Smeerdijk (1982), Botryococcus and Scenedesmus, all indicative of the eu- to mesotrophic conditions of open freshwater, but thriving best in eutrophic shallow pools (van Geel 2001; Montoya et al. 2010; Guiry and Guiry 2013).

Phase 3: ca. AD 1-550, Roman and beginning Migration Period (Pinus-Carpinus-NAP LPASZ, 467.5-575 cm)

During the oldest part of this phase some dropping in human activity and woodland return into open areas occurred. This could have been the result of dispersion of earlier concentrated settlement. Later, an increase in the pollen of human indicators coincides with the rise of the charcoal curve, reflecting activity associated with numerous Roman settlements situated in the vicinity of Lake Salęt (Fig. 4b). Open areas were used for cultivation, as denoted by the high percentages of Cerealia-type. The continuous $S$. cereale curve indicates that the onset of rye cultivation probably occurred at that time. The occurrences of Cannabis/Humulus-type together with Urtica are likely to be connected with human activity in the region.

Throughout this phase the smallest particles of microscopic charcoal were present at very high values, which is evidence of fires far away from the studied site. Fire could 
have served as a tool for clearing ground for cultivation and could have provided ash for fertilizing fields (by burning fields after harvesting, or by burning new wooded areas). Microcharcoals could also have come from daily hearth fires for cooking or settlement damaged by fire, which happened regularly, however by accident. The simultaneous occurrence of a wide range of NPP taxa, various algae (Botryococcus, Tetraedron, Scenedesmus, Zygnemataceae) and cyanobacteria (Aphanizomenon, Anabaena, Gloeotrichia) showed increasing eutrophication of the lake environment.

Phase 4: $c a$. AD 550-850, Migration Period and beginning of the early Medieval (Pinus-Corylus-NAP LPASZ, $397.5-467.5 \mathrm{~cm}$ )

The spread of some trees, mainly Pinus and Carpinus, but also Picea and Tilia, documents the development of the tree-covered areas. Despite the continuous occurrence of human indicators, including cultivated plants and weeds typical of permanent fields (e.g. Chenopodiaceae), the degree of anthropogenic vegetation changes declined slightly at about AD 550-600. Further vegetation changes confirm the increasing human influence on the environment around Lake Salęt. A high representation of ruderal plants and cereals indicate the existence of settlements and cultivated land nearby.

The pollen data from this phase (except for its early beginning) may be considered as a representation of continuous cultivation and cattle breeding. The contemporary presence of microcharcoals and several dung indicators provide further evidence of the persistent presence of livestock, with grazing in already established grassland periodically managed with fire, around Lake Salęt.

\section{Phase 5: ca. AD 850-920, Early Medieval (Alnus-Betula LPASZ, $380-397.5 \mathrm{~cm}$ )}

The period of intensive settlement, agriculture and animal husbandry was followed by a regression phase recorded in the pollen spectra at a depth of 380-395 cm and dated back to about AD 850-920 (Fig. 4). This time span is characterized by a decrease in the number and diversity of human pollen indicators, and it represents a period of a reduction in agricultural activities or relocation of open plots outside the investigated site. The AP/NAP ratio shows that the expanding woodland gained more ground at the expense of open grassland and agricultural fields. The setback in arable farming promoted regeneration of trees, especially of Betula (Betula sect. Alba-type), Pinus (Pinus sylvestristype), Alnus and Quercus. The population decreased, many farms were abandoned, and fields remained uncultivated. In the pollen diagram this event coincides with the decrease in Cerealia-type and Cannabis/Humulus-type. NAP frequency and concentration of charcoal particles diminish. However, pollen of Cerealia-type, S. cereale and Hordeumtype is still present, which means that agriculture remained a form of activity for the local population. The presence of charred particles in the largest class $(>100 \mu \mathrm{m})$ most probably points to activity within the settlement, rather than woodland clearing. In fact, agriculture and animal husbandry still existed.

Coprophilous fungi are more sporadic in comparison to the earlier period, although the presence of Cercophoratype (HdV112) and Sporormiella-type (HdV113) may well indicate dung and animal presence. Among the recorded fungal spores were spores of Ustulina deusta (Kretzschmaria deusta) (HdV44), known to be confined to wooded sites. Its occurrence around Lake Salęt agrees with the Alnus, Quercus and Fagus sylvatica trends, and these trees are all suitable hosts for this parasite (van Geel and Aptroot 2006). Kretzschmaria deusta has also been described as a very local tree cover indicator (van Geel and Andersen 1988), but it seems it can occur in sites at a $100 \mathrm{~m}$ distance from woodlands (Cugny et al. 2010).

\section{Geochemistry}

Values of K, Ti, Fe and Mn (Fig. 5) increase towards a maximum around $660 \mathrm{~cm}$ (human phase 1: $655-700 \mathrm{~cm}$ ), indicating an enhanced influx of minerogenic material as a result of overland flow, runoff or wind-driven transport of clastic material, most likely related to deforestation and erosion of uncovered soils. Elemental ratios of $\mathrm{Fe} / \mathrm{Mn}$ and $\mathrm{Fe} / \mathrm{Ca}$ show a similar pattern, with maximum values at depth $655-665 \mathrm{~cm}$ and a subsequent strong decrease that coincide with the period of intense erosion at the transition between human phase 1 and 2. Higher values of Fe/Ca may also indicate a greater eutrophy of the lake during that time. This may be related to enhanced nutrient transport from intensively eroded catchment soils. After this initial stage a constant decrease in erosion is observed, and more stable conditions are established at the end of human phase 2 $(575 \mathrm{~cm})$.

A transition between human phase 2 and 3 is marked by a considerable change in $\mathrm{Ca}$ content, from decrease in the older part of phase 2 to rapid increase at the onset of phase 3. However, this significant drop in $\mathrm{Ca}$ content at the transition zone between the two phases is not accompanied by an increase in any of the lithogenic elements. During human phase $3(467.5-575 \mathrm{~cm})$ a slow increase in Ti and $\mathrm{K}$, a relatively high content of $\mathrm{Ca}$, and stable values of $\mathrm{Fe}$ and $\mathrm{Mn}$ are observed.

No dramatic changes were observed either in human phase 4 (397.5-467.5 cm). Very stable conditions occurred without any geochemical evidence of remarkable erosion 


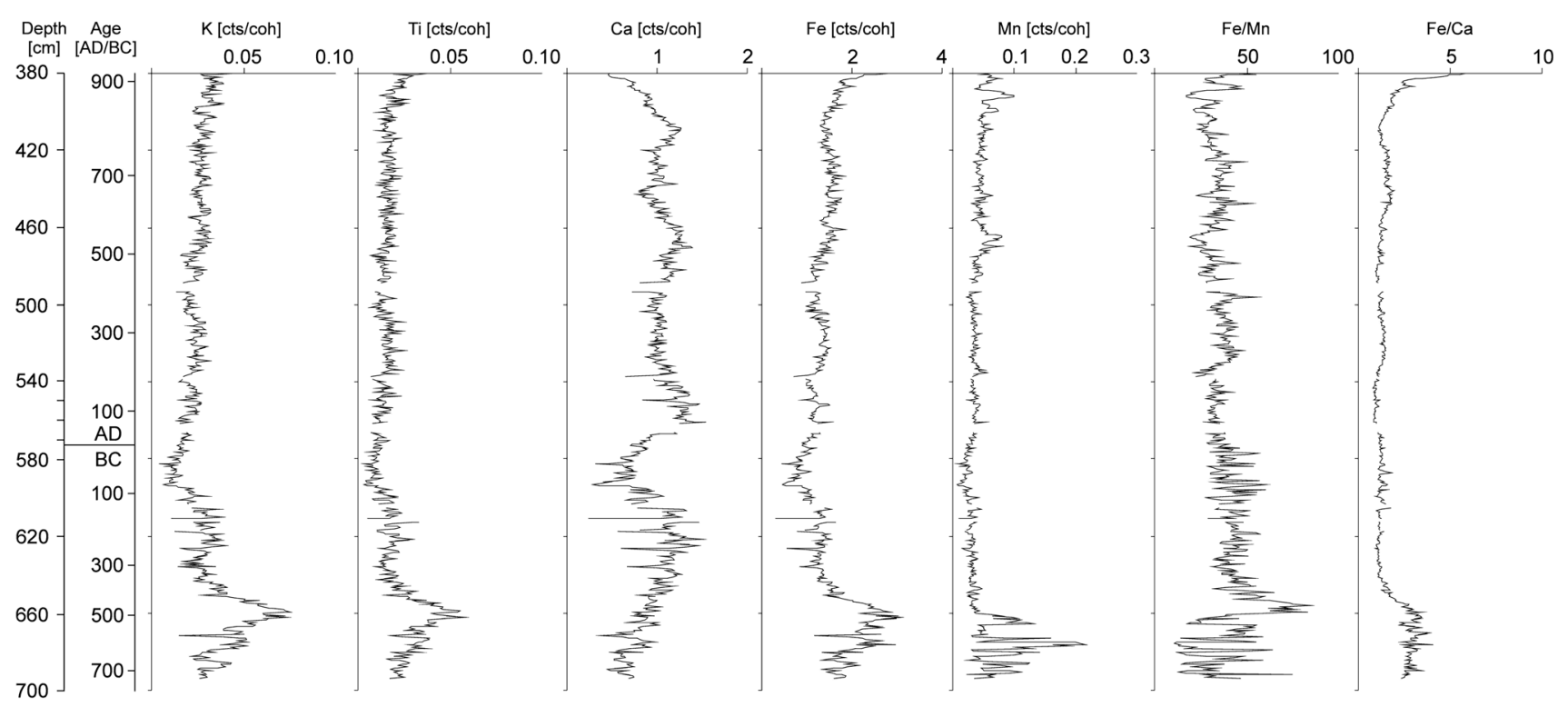

Fig. 5 Selected XRF-detected elements in the analyzed sediments of the Salęt core

or trophic status change. The only variable element was $\mathrm{Ca}$, which started to decrease from the oldest part of phase 4 . More variable conditions are recorded in phase 5 (380-397.5 cm) with an increase in $\mathrm{Ti}$ and $\mathrm{Fe}$, and a continuous decrease in Ca content. However, it is difficult to interpret this variability as phase 5 covers a very short time period and no information is available on further trends.

\section{Discussion}

Palaeoecological evidence for local land-use changes in the Iron Age

Recorded archaeological data indicate that the beginning of relatively stable settlements in the vicinity of Lake Salęt was connected with the development of the West Balt Barrow culture (Fig. 2) the agricultural activities of which were confirmed by our pollen analysis (Fig. 4b). From about ca. $500 \mathrm{BC}$, an increase in the frequency of a few anthropogenic indicators (e.g. Cerealia-type, Plantago lanceolata, Artemisia, Poaceae, Rumex acetosa-type, Ranunculus acris-type, Chenopodiaceae) and an appearance of several others (e.g. Secale cereale, Triticum-type) is documented in the Salęt pollen profile (Fig. 4b). Moreover, the increasing anthropogenic settlement activity in the catchment area of Lake Salęt accelerated the eutrophication processes that stimulated growth of algae and cyanobacteria. In Estonia, which was also within the range of the West Balt Barrow culture, the persistent presence of crop taxa testifies to continuous agrarian activity from the Iron Age (since ca. 500 BC), when the percentage of cultivation indicators increases significantly (Poska et al. 2008).

The relatively high peaks of $P$. lanceolata and Poaceae as well as the increase in frequency of Filipendula, $R$. acetosa-type, Apiaceae and Cichorioideae pollen (Fig. 4b) document a large area of meadows and pastures, which suggest that free-grazing cattle played a major role in the agricultural economy of that time. The presence of coprophilous fungi ascospores of Cercophora-type may confirm this type of activity in the close vicinity of the studied lake (cf. Cugny et al. 2010). According to Iversen (1973), P. lanceolata is one of the most important plants in old-fashioned rough pastures, but it will not grow in grazed woodlands because of its high light requirements. Behre (1981) emphasized that this plant plays an important role in the recolonisation of fallow land, and hence is a diagnostic species of an earlier system of rotational farming. Being an indicator of fallow land, which was usually used as pasture, $P$. lanceolata indirectly indicates former cultivation, which can often be difficult to demonstrate (Behre 1981, 1986) due to the poor dispersal of Cerealia pollen (Vuorela 1973). Thus, a continuous $P$. lanceolata curve (from ca. 550 BC) (Fig. 4b) indicates cattle breeding and also possible cultivation in the investigated area.

The initial deforestation caused the most prominent increase in erosion intensity in the catchment during the analyzed period, which is well documented by significant elemental changes in the sediment, i.e. peaks in potassium, titanium, iron and manganese content around ca. $500 \mathrm{BC}$ 
(Fig. 5). Interestingly, subsequent deforestation did not produce such a clear signal in the chemical composition of the sediments.

A further increase in anthropogenic impact on the vegetation of the Lake Salęt surroundings was recorded at ca. AD 150 when new activities in crop cultivation and cattle rearing started (Fig. 4b). Recorded archaeological data indicate that the Roman Period was a time of general demographic and economic expansion on the whole southeastern coast of the Baltic Sea (Karczewski 2012). Settlement of that time was related here to the Bogaczewo culture, numerous sites of which were also discovered around Lake Salęt (Fig. 2).

Vegetation changes related to the Bogaczewo culture activity were characterized by an increased diversity of herbaceous plants treated as anthropogenic indicators, particulary cereals (besides pollen of $S$. cereale there appeared Hordeum-type, Triticum-type and Avena-type), and by the increase in the presence of charcoal, which suggests that slash-and-burn agriculture could have been the major cultivation method in Lake Salęt area.

During this period Secale cultivation spread in the vicinity of Lake Salęt. S. cereale was common in all of Europe as early as from the beginning of the Christian era, but it grew as a weed in Hordeum and Triticum fields. When grain cultivation moved north, the importance of Secale as the most frost-resistant cereal increased until the point where it began to be cultivated as a separate crop (Behre 1992). The results of palynological research show that almost throughout Estonia, Secale came to be cultivated in about the 6th century AD (Poska et al. 2004, 2008), but in north-western Estonia perhaps even earlier, in the Roman Iron Age (Heinsalu and Veski 2010). The relatively high frequency of $S$. cereale pollen noted in the Salęt profile (Fig. 4b) could be partly explained by Secale pollen dispersal by wind. This crop has higher pollen production and better dispersal potential than other cereals (Koff and Punning 2002). Vuorela (1973) studied the variation in pollen rain in the vicinity of an agricultural area surrounded by forest in Finland, and her principal conclusion was of the pollen filtering action of the forest. If the pollen of $S$. cereale is well dispersed and is found in peat-bogs and lake sediments far away from cultivated areas, then its frequencies must represent regional background values. Thus, in our investigation the $S$. cereale frequencies in the Salęt profile could reflect the regional background, which has to be taken into account when interpreting the diagram. The increased diversity of settlement and farming indicators was also observed for that period in some other sites from NE Poland, e.g. at about AD 100-650 in the surroundings of Miłki and at about AD 50-500 in the Staświny-Ruda and Lake Łazduny region (Wacnik et al. 2012). Wacnik et al. (2012) concluded that meadows and fields were that time the permanent, though not the dominant element of the local landscape.

Intensive agriculture and the broad extent of disturbed soils with high $\mathrm{NO}_{3}$ content in the vicinity of Lake Salęt are documented by the wide presence of typical weeds (Rumex acetosella-type, Artemisia and Chenopodiaceae) from the second to the 5th century AD. The smallest particles of microscopic charcoal were present here at very high values from the second half of the 4th century $\mathrm{AD}$, which suggests that fire could have served as a tool for clearing ground for cultivation and could have provided ash for fertilizing fields. In the light of our pollen data there is no record of a demographic crisis at the end of the fourth and in the early 5th century, as is suggested by some archaeological data in this region (e.g. Szymański 2005; Bitner-Wróblewska 2010).

Evidence for cattle rearing activity also comes from the fungal spore record, with the dung-inhabiting taxa (Cercophora-type and Sordaria-type). Cercophora comprises species which occur regularly on decaying wood, culms, stems and leaves (Ellis and Ellis 1997), but in an archaeological context this fungus can be used as an indicator for the presence of animal dung (van Geel and Aptroot 2006). The dispersal and transport of the fungal spores is less efficient in comparison with tree pollen, probably partly because of the position of fungal fruit bodies near the ground, where wind dispersal is less effective, and therefore the records of spores of coprophilous fungi can be used as indicators of the presence of animals near the sample site (van Geel et al. 2003).

The increasing human impact in the catchment area of Lake Salęt, as can be interpreted from the pollen records of human impact indicators, had its effect on the trophic conditions of this lake water. The simultaneous occurrence of NPP taxa, such as various algae (Botryococcus, Tetraedron, Scenedesmus, Zygnemataceae) and cyanobacteria (Aphanizomenon, Anabaena, Gloeotrichia) showed increasing eutrophication of the lake environment.

Some more information about the economy of West Balts tribes during the Roman Period comes from archaeobotanical and archaeozoological investigations at several sites in Masuria, for instance at Jeziorko in the Great Lakes Masurian District (Zabłocki 1950; Grezak and Piotrowska-Malecka 2007), Pieczarki (Polcyn 2000) and Wyszembork in the Mrągowo Lake District (LityńskaZajacc 1997). At the Wyszembork site, which is located close to Lake Salęt, abundant material of charred cereal grains contained Hordeum vulgare, Secale cereale and Panicum miliaceum. Seeds of Cannabis sativa, Pisum sativum and Brassica cf. campestris, possibly also cultivated, were found. Among field weeds there appeared, for instance, Centaurea cyanus, Echinochloa crus-galli, Chenopodium album and Scleranthus annuus (Lityńska-Zając 1997). 
Judging from these results, Cannabis sativa cultivation in the close vicinity of Lake Salęt is confirmed both by the archaeobotanical data and pollen data from the Salęt profile (Fig. 4b).

The increase in the importance of crop farming, combined with the need for new agrarian land, could have resulted in the clearing of areas with fertile soils occupied earlier by Alnus stands or mixed woods with high Alnus content (cf. Saarse et al. 2010). The preference for Alnus stands as the first choice in slash-and-burn cultivation could be motivated by the fact that as an $\mathrm{N}_{2}$-fixing tree Alnus can itself fertilise soil with atmospheric nitrogen (Uri et al. 2003). The use of iron tools increased the need for iron, and it is possible that Alnus wood was used as a fuel for iron smelting, which in turn would also diminish the Alnus population. Alnus is known as a rich pollen producer (Rasmussen 2005) thus its percentage is high in the whole diagram (Fig. 4). However, a decrease in the Alnus pollen curve began about $\mathrm{AD} 540$, as in the other European lake sediment sequences, which registered a significant Alnus decline between AD 300 and 1000 (e.g. Sarmaja-Korjonen 2003; Veski et al. 2005; Saarse et al. 2010). In northeastern Europe, Alnus pollen percentages diminished sharply during the Iron Age, which coincided with the start of extensive crop farming (Punning et al. 1995; SarmajaKorjonen 2003; Veski et al. 2005; Niinemets and Saarse 2007b; Saarse et al. 2010).

Pollen data from the Salęt profile indicate that the same land-use practices as in the Roman Period seem to have continued into the Migration Period. Settlement of the Olsztyn Group developed then in the surroundings of Lake Salęt (Fig. 2). Among palynological indicators of agricultural activity pollen grains of cereals ( $S$. cereale, Hordeumtype, Avena-type) and Cannabis/Humulus-type pollen were present (Fig. 4b). In the older part of this phase the degree of anthropogenic vegetation changes declined temporarily, although the occurrence of herbs, including weeds typical of permanent fields (e.g. Chenopodiaceae) was noted regularly. Then further vegetation changes dated to about $\mathrm{AD}$ 600 indicate the increasing human influence on the environment around Lake Salęt. These are a high representation of ruderal plants and a continuous cereal curve and these indicate the existence of settlements and cultivated land nearby. Charcoal is a particularly useful proxy for recording the disturbance of vegetation by humans. Its peak values occured together with a pronounced drop of tree pollen and a significant rise of anthropogenic pollen (Fig. 4). It is worth mentioning that the pollen record from the eastern part of the Masurian Lakeland (Wacnik et al. 2012) showed a distinct difference between the intensity of vegetation changes caused by man in comparison with our data. The traces of economic-settlement activity recorded in those pollen diagrams indicate its decline in the vicinity of Lakes Miłkowskie, Wojnowo and Łazduny about $\mathrm{AD}$ 600-1000 (Wacnik et al. 2012).

In some European pollen diagrams slightly elevated percentage values of Cannabis/Humulus-type range from ca. AD 400 to 1500 . This is apparent in the pollen records from Sweden (Påhlsson 1982), Finland (Sarmaja-Korjonen 2003), Denmark (Rasmussen 2005) and Lithuania (Stančikaitè et al. 2008) and correlates well with the Salęt data. In Lithuania macroremains and pollen of Cannabis sativa were found in sediments dated back to about $\mathrm{AD}$ 430-620 (Stančikaite et al. 2008) and this suggests that this taxon may have been introduced and widely cultivated in this period. Interesting evidence comes from archaeobotanical investigations conducted in southwestern Germany showing that from the 3rd to the 6th century $\mathrm{AD}$ beer was made mainly from not very pure Hordeum malt, but with the addition of honey, and probably flavoured with Humulus lupulus (Rösch 2008). It is possible that in NE Poland there were also such a practice related to the Bogaczewo culture and the Olsztyn Group activity.

Among the NPPs recorded in the assemblage zone related to the Migration Period are fungal spores indicative of the presence of dung, namely Sporormiella-type, Sordaria-type and Cercophora-type as well as egg shells of the intestinal parasite Trichuris, which point to the deposition of excrement (van Geel et al. 1983). Sporormiellatype is also known as a strictly local grazing pressure indicator (Blackford and Innes 2006; Davis and Shafer 2006) and is commonly used for past grazing pressure reconstruction (van Geel et al. 2003; Gauthier et al. 2010). Dietre et al. (2012) confirmed the indicative power of this taxon as coprophilous fungi and documented its association with open habitats. Considerable numbers of akinetes of Aphanizomenon and Anabaena have been found at this time in the Salęt profile. These cyanobacteria can be considered as an indication of increased nutrient loading, related to the above-mentioned contemporaneous increase of human impact in the catchment area. Their dominance could be explained by an increase in phosphorus, which commonly occurs in eutrophicated waters (van Geel et al. 1994). According to our palynological data, anthropogenic changes in the environment, which started during the Migration Period, lasted until the mid 9th century.

The anthropogenic impact on the landscape during that period, which is distinctly evidenced by the pollen diagram, is not reflected by the archaeological data. Most of the data postulate a decline of settlement from the 7 th century (e.g. Kowalski 2000; Nowakowski 2000). However, this conception is based mainly on studying cemeteries and may not reflect actual depopulation, but only changes in burial practices (e.g. Wróblewski et al. 2003). Reinterpretation of the data in the context of new studies on the distribution of pottery styles suggests that here the 
settlement could have been maintained up to the 9th century (Paweł Szymański: personal communication). Also some historians suggest that in some regions of the Masurian Lakeland settlement was scattered but still persisted till the Early Medieval (e.g. Białuński 1999).

\section{Local development of Betula in a European perspective}

From the beginning of the early Iron Age, the existence of deforestation favouring the expansion of Betula is indicated by the increased percentages of herbaceous plants (Fig. 4). According to Lindbladh et al. (2003) human activity and fire could have been important factors for the long-term recorded dominance of Pinus, Betula and some other species in northern Europe during last 2,500 years. These authors emphasised that many Pinus trees can survive mild to moderate fires, whereas Betula is a prominent pioneer species after fires. The pollen assemblage zone representing this period in the Salęt profile (Betula-Corylus-NAP) is dominated by Betula pollen up to $35 \%$, suggesting that Betula was the dominant taxon among trees. It has been assumed that a minimum value of $10 \%$ of Betula pollen may indicate its local presence, values larger than $25 \%$ indicates local Betula-dominated woodlands, and more than $50 \%$ reflects Betula-dominated woodlands which cover the landscape (Huntley and Birks 1983). Isopollen maps for 600-60 BC show the distinct increase of Betula pollen values to about $25 \%$ in north-eastern Poland (Ralska-Jasiewiczowa et al. 2004). This process is also evident in the profile from Lake Dgał Wielki (FilbrandtCzaja 2000), and slightly less clearly in Lake Mikołajskie (Ralska-Jasiewiczowa 1966). In the other profiles from the Masurian Lake District, the Betula pollen percentages remain on a high level (25-40 \%) for a long period as is recorded in Lakes Łazduny, Miłkowskie and Wojnowo (Wacnik et al. 2012) as well as in Lake Linówek (Gałka et al. 2014). These authors mostly concluded that the reason was that the landscape was cleared repeatedly in order to prevent woodland succession within the settlement region. Systematic clearings were connected with shortlasting agricultural use of the ground, which required temporary resting. They also noted the occurrence of micro-charcoals $>100 \mu \mathrm{m}$ which indicates local intentional use of fire, probably in the course of slash-and-burn agriculture, known also as swidden or shifting agriculture (Cornell 2011). This system involves the rotation of several plots in a planting cycle and works best in low intensity agriculture, when there is enough space for fallow land. Using the traditional Fennoscandian method, the trees were cut down and left to dry 1 year before burning, while cultivation took place in the following few years. The land was then left for reforestation, or turned into pastures during the fallow periods (Sjögren and Arntzen 2013). This method was similar in other countries on the eastern coast of the Baltic Sea, where farming societies were established in Lithuania, Latvia and Finland during the Late Bronze Age at the earliest (Antanaitis-Jacobs and Girininkas 2002).

There is a general assumption that fire events during the late Holocene in Europe and western Asia can be explained by deforestation using fire, especially during the Bronze and Iron Ages (Power et al. 2008). In contrast to earlier woodland clearances, after which regeneration normally occurred, Iron Age clearances often resulted in a permanent change in the ecosystem. Implementation of iron tools, ploughing and manuring enabled people to extend the size and number of fields and to exploit less favourable areas. In addition, increases in crop and non-arboreal pollen (AP) were often accompanied by evidence of fire use in woodland clearances visible as woodland composition changes. In general, the proportions of temperate broadleaved trees and Picea decrease at the same time as Betula and Pinus increase. This feature is apparent in several records from Estonia, Latvia and Lithuania (Stančikaitè et al. 2006; Heikkilä and Seppä 2010). However, in some regions in Estonia the woodland composition changes took place earlier than the start of the continuous crop pollen curve and other evidence for large-scale arable farming (Veski et al. 2005; Niinemets and Saarse 2007a). High values of Betula pollen, up to $35 \%$, that were contemporary with low frequencies of charcoal particles in the pollen assemblages associated with West Baltic Barrow culture in the profile from Lake Salęt allowed us to formulate a hypothesis about the agricultural practices in this area. Tentatively we suggest that felling trees rather than burning served as a tool for clearing ground for cultivation in the investigated microregion.

Agricultural exploitation of the study area became stronger from the second half of the 2nd century $\mathrm{AD}$ (Roman Iron Age). Numerous charred particles detected in sediments from this period suggest the use of fire for land clearing. This technique apparently favoured the spread of Betula (30-35 \%). The gradual increase of Betula pollen during the Roman Iron Age was observed also in Lithuania, to ca. $10 \%$ in the area of Baltija Upland (Stančikaite et al. 2004) and to 25-30\% in the Biržuli Lake region (Stančikaité et al. 2006), and both were interpreted as human induced vegetation changes. Several pollen diagrams from Sweden also show high frequencies of Betula pollen at levels dated to the Iron Age, as is evident, for example, in the pollen maps presented by Björse and Bradshaw (1998). In southern Sweden a new agro-technical system was introduced during the first centuries $\mathrm{AD}$ (Lagerås and Bartholin 2003). This was hay production, which presumably resulted in increased manuring and hence longer cultivation periods between fallow phases. 
The new, more open spaces created during human expansion phases favoured light-demanding shrubs and trees like Betula and Corylus.

Betula expansion in the area of Lake Salęt intensified during the later stages of the Iron Age. The pollen diagram (Fig. 4a) shows fluctuating Betula values (25-43\%) during the Migration Period (end of the Pinus-Carpinus-NAP and Pinus-Corylus-NAP LPASZ). These fluctuations in the Betula pollen proportion together with the increase in the amounts of charcoal particles and cereal pollen can be interpreted as the evidence for the shrub-fallow type agrotechnical system. There are several examples of this system across Europe. In the Carpathians a 10-year cycle shrub-fallow system was used. The shrubs were cut down in the middle of the summer and allowed to dry. The next year they were burnt and the ashes worked into the soil. The first year Hordeum was cultivated, followed by 2 years of Avena, after which the fields were left to regenerate (Emanuelsson 2009). Around the North Sea different systems were used. In one of them, the grass turf was broken up, allowed to dry, and subsequently burnt (Emanuelsson 2009). In prehistory the shrub-fallow cultivation system existed in a multiplicity of variants, and it is probably not possible to find its exact analogue in recent history. Sjögren and Arntzen (2013) describe a hypothetical shrub-fallow system in which after a 5-15 year fallow period the shrubs were cut down and/or the turf broken up and allowed to dry. After burning the dried plants, the soil was reworked and cultivated for no more than 2-3 years. It is possible that this activity resulted in depletion of the soil nutrients within 5-10 cycles. Sjögren and Arntzen (2013) suggest that this forced the farm to move, or to turn previous pastureland into arable land and vice versa. Alternatively, or in addition to this, the slash-and-burn practice and the use of the ashes to provide nutrients to the soil could be employed. The main reasons for the high yields after burning are the mobilization of nutrients, the rise in $\mathrm{pH}$, which makes nutrients more easily available, especially for Triticum, and the suppression of weeds (Rösch et al. 2004). In our investigation, high values of Betula pollen observed during the whole of the Iron Age could be related to secondary communities with Betula as the dominating taxon that invaded heavily cleared places. The possibility of using ash for manuring impoverished soils was restricted by the limited availability of wood suitable for burning, which in turn necessitated longer periods of leaving the exploited areas fallow (Rösch et al. 2004; Wacnik et al. 2011). The source of wood could be provided by quickly growing Betula thickets, which were common on fallow land. It should be noted here that Betula, the most likely taxon to colonize the fallow land, does not start to produce pollen until after about 10 years when standing alone and free, and in compact stands not before 20-25 years (Tomanek 1966). Slash-and-burn cultivation was used in many parts of Europe up to the 20th century, e.g. in South Estonia up to the end of the Second World War (Niinemets and Saarse 2006; Poska et al. 2008).

Effects of climate change on agriculture and population of prehistoric Balts

The Bronze/Iron Age transition in Europe has long been recognized as a period of climate deterioration, corresponding approximately to changes in peat sequences defining the Subboreal/Subatlantic transition in the BlyttSernander scheme for division of the Holocene (Sernander 1908), reflecting a shift from warm/dry to relatively cool/ wet conditions. Whether this change in atmospheric circulation patterns was primarily triggered by changes in solar activity (e.g. van Geel et al. 1999) or by changes in the thermohaline circulation (e.g. Bond et al. 1997) is still debatable. Despite the abundant evidence for widespread climate change in the late Bronze and early Iron Age, and archaeological indications of settlement abandonment at some sites, it is unclear how significant this change was for human settlement and land use (Dark 2006). The cooling of climate and increase in precipitation between 800 and 600 $\mathrm{BC}$ was a time when the glaciers in the Alps were growing (Holzhauser et al. 2005) and accumulation on the peat bogs increased (Gałka et al. 2013). On the basis of oxygen isotope records from Greenland ice-cores, Tinner et al. (2003) indicated that warm periods existed among others at around 650-450 BC. This was when the most significant changes in the cultural landscape of north-eastern Poland occurred, West Balt Barrow culture appearing in Masuria (e.g. Hoffmann 2000). In the pollen profile from Lake Salęt noticeable peaks in Cerealia-type and Plantago lanceolata pollen (ca. 1-2 \%) are dated to ca. $441 \mathrm{BC}-\mathrm{AD} 86$, and express intensified agriculture around this site. According to Büntgen et al. (2011) in central Europe, construction activity increased during the Iron Age, from ca. $300 \mathrm{BC}$ to $\mathrm{AD} 200$, and the maximum deforestation occurred around AD 250.

In north-eastern Poland continuous and increasing pressure on vegetation, including formation of arable plots and pastures, began from the Late Bronze Age and increased considerably during the Roman Iron Age (e.g. Wacnik 2009, Wacnik et al. 2012), when the Bogaczewo culture developed in the Masurian Lakeland (e.g. Szymański 2005; Karczewski 2011). Archaeologically documented innovations in agriculture, like iron tools (e.g. sickles) and efficient ox-pulled ploughs increased agricultural productivity during the Iron Age and this coincided with changes in the pollen of cultivated plants. The adoption of these innovations is likely to be responsible for the 
increasing long-term trends observed in our data. Similarly, the Roman Iron Age in Sweden was a period of agrarian expansion, intensification and innovation when the new agro-technical systems were introduced (cf. Lagerås and Bartholin 2003). According to the pollen data from the Salęt profile (Fig. 4b), at about AD 540-590 a short lasting decline of non-AP frequencies took place, particularly a sharp decrease in pollen of cultivated plants and weeds. Then a reforestation of open fields occurred with Betula and Corylus as well as broad-leaved species, i.e. Quercus and Carpinus, in the later stages. This could have been caused by the abandonment of settlements as well as by migration of some groups of people. However, the overall impression from archaeological studies implied that a presumably small human population was living there and so did not significantly influence the regional environment. The settlement regression could also be identified as the result of extensive dispersion of earlier concentrated intensive activity of Bogaczewo culture people (Szymański 2005), and it is possible that this was related to environmental changes.

The existence of important climate changes that affected the Baltic area and neighbouring European regions in the 5th-6th centuries AD is shown by many palaeoecological investigations. For example, oxygen isotope records from Greenland show a general decreasing temperature trend after AD 400 (Tinner et al. 2003). Furthermore, there are a number of wet/cold records during the period at ca. AD 450-550, noted in the bogs of England, Scotland, Ireland, Denmark and the Netherlands (Hughes et al. 2000; Barber et al. 2004), which suggest general climatic deterioration in northern Europe. Moreover, in the eastern Baltic Sea region, high-resolution palaeoecological studies of Männikjärve bog in Estonia have provided evidence of a higher surface water table ca. AD 400 as a response to cooler climate (Sillasoo et al. 2007, 2009). These phenomena coincide with the biggest central European historical crisis, the Migration Period, a time marked by lasting political turmoil, cultural change and socioeconomic instability, when exceptional climate variability is reconstructed (Büntgen et al. 2011). At the same time, hemispheric-scale cooling occurred that has been linked with an explosive nearequatorial volcanic eruption in AD 536 followed by the first pandemic of Justinian plague that spread from the eastern Mediterranean in AD 542-543 (Kausrud et al. 2010). Rapid climate changes together with frequent epidemics had the overall capacity to disrupt the food production of agrarian societies (e.g. de Menocal 2001; Haug et al. 2003). Precipitation and temperature began to increase from the end of the 6th century $\mathrm{AD}$ and reached climate conditions comparable to those of the Roman Period in the early 9th century AD (Büntgen et al. 2011). In many regions of northern Germany and neighbouring areas a general decline of settlement activities started from ca. AD 400 to 500 (Dörfler 1992; Karge et al. 2000; Beug 2011), and archaeological and palaeobotanical indicators of settlement activities almost disappeared between AD 500 and 900 (Müller-Wille et al. 1988). To some extent, the changes noted around these times do not have to be seen as confined only to central Europe. In Scandinavia, around AD 500 there is a drastic decline in cereal pollen. In the 6th century many settlements seem to have been completely abandoned and expanded again only in the late Viking Age (Liedgren 1992; Brink 1994; Löwenborg 2012). However, recent investigations in Lithuania (e.g. Bliujiene 2003; Simniškytė et al. 2003; Stančikaitė et al. 2013) have demonstrated rather high ongoing settlement activity, including agriculture practices, in particular areas of the Eastern Baltic during the Migration Period. Archaeological data representing this time interval attest to changing site occupation systems when hill forts were abandoned and low-lying settlements were enlarged (e.g. Stančikaite et al. 2013).

\section{Conclusions}

Pollen, NPPs, charcoal and geochemical analyses were conducted on sediments from Lake Salęt being the central point of the settlement microregion. The investigations were restricted mainly to the Iron Age, and covered the period from the second half of the 7th century $\mathrm{BC}$ to the beginning of the 10th century AD. The palaeoecological data, together with a well established chronology, made it possible to correlate local environmental changes with archaeological finds of human settlements, and confirmed the long-lasting existence of the West Balt tribes in the Mrągowo Lake District.

The results obtained provided new data to assess the dynamics of settlement and economic changes of the prehistoric inhabitants of the Mraggowo Lake District (NE Poland). The whole Iron Age in the studied region was characterized by the almost continuous existence of the West Balt tribes, which was connected with the West Balt Barrow culture, and then with the Bogaczewo culture and the Olsztyn Group. Correlation of palaeoecological data with the local archaeological data was a reliable basis for the interpretation of man-environment interactions.

The diversification of the use of the environment by humans is quite clearly marked in particular periods of the Iron Age. In the early Iron Age (West Balt Barrow culture) the mainstay of the economy was animal husbandry, and cultivation was of rather less significance (probably mainly Triticum was grown). In the Roman Period (Bogaczewo culture) animal husbandry and cultivation were of more or less similar economic importance, and Secale cultivation 
was introduced on a large scale. Slash-and-burn cultivation developed, particularly in the middle part of the Roman Period, after ca. AD 200. In the Migration Period (Olsztyn Group) the economic activity of the Roman Period was continued and judging from the pollen record, human impact on vegetation persisted until the 9th century. Regeneration of woodlands, mainly Betula woodlands and Alnus woods took place only in the period after ca. AD 830, and was accompanied by a decrease of all indicators of agriculture. This observation is not in accordance with the most of archaeological data about the diminishing of the settlement activity in the Salęt microregion as early as the 7th century AD.

The most characteristic feature of the studied area during the whole Iron Age was a high representation of seminatural Betula woodlands which was probably linked with the shifting agriculture. However, strong reduction in Betula took place between ca. 650 and 450 BC and was connected with the appearance of the West Balt Barrow culture.

Plausibly, climate changes were a major factor shaping changes in settlement and land-use patterns in the Iron Age. Broadly, at around $400 \mathrm{BC}$ there was a marked increase in the number of Balts settlements in the area around Lake Salęt connected to climate warming. Moreover, the economic and societal crisis at about AD 540-590 might have been aggravated by climate deterioration in the Migration Period.

Acknowledgments We are especially indebted to Małgorzata Latałowa for valuable suggestions. We would like to express our gratitude to Dorota Nalepka and Adam Walanus for their valuable support. We are grateful to Felix Bittmann and an anonymous reviewer for comments on the manuscript. We would like to cordially thank Daniela Czerniawska for help with sample preparation. We acknowledge the financial support provided by the Ministry of Science and Higher Education/National Science Centre of Poland (Grant No. N N 304 280540), and by the Institute of Biology, University of Białystok, through statutory funds.

Open Access This article is distributed under the terms of the Creative Commons Attribution License which permits any use, distribution, and reproduction in any medium, provided the original author(s) and the source are credited.

\section{References}

Alenius T, Mikkola E, Ojala AEK (2008) History of agriculture in Mikkeli Orijärvi, eastern Finland, as reflected by palynological and archaeological data. Veget Hist Archaeobot 17:171-183

Anderson RS, Homola RL, Davis RB, Jacobson GL Jr (1984) Fossil remains of the mycorrhizal fungal Glomus fasciculatum complex in postglacial lake sediments from Maine. Can $\mathrm{J}$ Bot $62: 2,325-2,328$

$\checkmark$ Antanaitis-Jacobs I, Girininkas A (2002) Periodization and chronology of the neolithic in Lithuania. In: Kazakevičius V, von Carnap-
Bornheim C, Hines J, Žulkus V (eds) Archaeologia Baltica. Vilnius University, Vilnius, pp 9-39

Bakker M, van Smeerdijk DG (1982) A palaeoecological study of a late Holocene section from 'Het Ilperveld', western Netherlands. Rev Palaeobot Palynol 36:95-163

Barber K, Chambers FM, Maddy D (2004) Late Holocene climatic history of northern Germany and Denmark: peat macrofossil investigations at Dosenmoor, Schleswig-Holstein, and Svanemose, Jutland. Boreas 33:132-144

Bednarek R, Prusinkiewicz Z (1999) Geografia gleb. PWN, Warszawa

Behre KE (1981) The interpretation of anthropogenic indicators in pollen diagrams. Pollen Spores 23:225-245

Behre KE (1986) Anthropogenic indicators in pollen diagrams. Balkema, Rotterdam

Behre KE (1988) The role of man in European vegetation history. In: Huntley B, Webb T (eds) Vegetation history. Handbook of vegetation science. Kluwer, Dordrecht, pp 633-672

Behre KE (1992) The history of rye cultivation in Europe. Veget Hist Archaeobot 1:141-156

Bell A (1983) Dung fungi. Victoria University Press, Wellington, An illustrated guide to coprophilous fungi in New Zealand

Berglund BE, Ralska-Jasiewiczowa M (1986) Pollen analyses and pollen diagrams. In: Berglund BE (ed) Handbook of Holocene palaeoecology and palaeohydrology. Wiley, Chichester, pp 455-484

Beug HJ (2004) Leitfaden der Pollenbestimmung für Mitteleuropa und angrenzende Gebiete. Pfeil, München

Beug HJ (2011) Vegetation changes during the Slavic period, shown by a high resolution pollen diagram from the Maujahn peat bog near Dannenberg, Hanover Wendland, Germany. Veget Hist Archaeobot 20:199-206

Białuński G (1999) Studia z dziejów plemion pruskich i jaćwieskich. Rozprawy i Materiały OBN, Olsztyn

Bitner-Wróblewska A (2008) Observers or participants? The Balts during the turbulent epoch. In: Niezabitowska-Wiśniewska B, Juściński M, Łuczkiewicz P, Sadowski S (eds) the turbulent epoch. New materials from the Late Roman Period and the Migration Period, Monumenta Studia Gothica V, Lublin, pp 97-112

Bitner-Wróblewska A (2010) North-eastern Poland in first centuries AD: a world apart. In: Lund Hansen U, Bitner-Wróblewska A (eds) Worlds apart? Contacts across the Baltic Sea in the Iron Age network Denmark-Poland, 2005-2008. København, Warszawa, pp 141-184

Björse G, Bradshaw R (1998) 2000 years of forest dynamics in southern Sweden: suggestions for forest management. Forest Ecol Manage 104:15-26

Blackford JJ (2000) Charcoal fragments in surface samples following a fire and the implications for interpretation of subfossil charcoal data. Palaeogeogr Palaeoclimatol Palaeoecol 164:33-42

Blackford J, Innes J (2006) Linking current environments and processes to fungal spore assemblages: surface NPM data from woodland environments. Rev Palaeobot Palynol 141:179-187

Bliujienė A (2003) A microregion between Šilute-Priekule and Švèkšna in western Lithuania or alternatively the Lamata land according to archaeological data. Archaeologia Lituana 4:122-135

Bond G, Showers W, Cheseby M, Lotti R, Almasi P, de Menocal P, Priore P, Cullen H, Hajdas I, Bonani G (1997) A pervasive millennial-scale cycle in North Atlantic Holocene and glacial climates. Science 278:1,257-1,266

Brink S (1994) Hälsinglands äldre bebyggelsehistoria. Ett forsök till en syntes. Bebyggelsehistorisk tidskrift 27:153-172

Bronk Ramsey C (2010) OxCal Program, v. 4.1.7, Radiocarbon accelerator unit, University of Oxford, UK. http://c14.arch.ox.ac. uk/embed.php?File=oxcal.html. Accessed 27 March 2013 
Büntgen U, Tegel W, Nicolussi K, McCormick M, Frank D, Trouet V, Kaplan JO, Herzig F, Heussner KU, Wanner H, Luterbacher J, Esper J (2011) 2500 years of European climate variability and human susceptibility. Science 331:578-582

Clark JS (1988) Stratigraphic charcoal analysis on petrographic thin sections: application to fire history in northwestern Minnesota. Quat Res 30:81-91

Collis J (1984) The European Iron Age. Routledge, London

Cornell J (2011) Slash and burn. http://www.eoearth.org/view/article/ 156045. Accessed 10 Nov 2013

Croudace IW, Rindby A, Rothwell G (2006) ITRAX: description and evaluation of a new multi-function X-ray core scanner. In: Rothwell RG (ed) New Techniques in Sediment Core Analysis. Special Publications, London, The Geological Scociety of London, pp 51-63

Cugny C, Mazier F, Galop D (2010) Modern and fossil non-pollen palynomorphs from the basque mountains (western Pyrenees, France): the use of coprophilous fungi to reconstruct pastoral activity. Veget Hist Archaeobot 19:391-408

Dark P (2006) Climate deterioration and land-use change in the first millennium BC: perspectives from the British palynological record. J Archaeol Sci 33:1,381-1,395

Davis OK, Shafer DS (2006) Sporormiella fungal spores, a palynological means of detecting herbivore density. Palaeogeogr Palaeoclim Palaeoecol 237:40-50

de Menocal PB (2001) Cultural responses to climate change during the late Holocene. Science 292:667-673

Dietre B, Gauthier E, Gillet F (2012) Modern pollen rain and fungal spore assemblages from pasture woodlands at Lake Saint-Point (France). Rev Palaeobot Palynol 186:69-89

Dörfler W (1992) Landscape development about 6500 BP and about 500 AD Kosel, Schleswig-Holstein. In: Frenzel B (ed) Evaluation of land surfaces cleared from forests by prehistoric man in Early Neolithic times and the time of migrating Germanic tribes. Stuttgart, Jena, New York, pp 161-167

Ellis MB, Ellis JP (1997) Microfungi on land plants. An identification handbook. New enlarged edition, Richmond, Slough

Emanuelsson U (2009) Europeiska kulturlandskap: hur människan format Europas natur (Cultural landscape of Europe: how man changed European nature). Formas, Stockholm

Filbrandt-Czaja A (2000) Vegetation changes in the surroundings of Lake Dgał Wielki in the light of pollen analysis. In: Kola A (ed) Studies in Lake Dwellings of West Baltic Barrow Culture. UMK, Toruń, pp 89-99

Gaillard MJ, Berglund BE (1988) Land-use history during the last 2700 years in the area of Bjäresjö, Southern Sweden. In: Birks H, Birks HJB, Kaland PE, Moe D (eds) The cultural landscape: past, present and future. Cambridge University Press, Cambridge, pp 409-428

Gałka M, Miotk-Szpiganowicz G, Goslar T, Jęśko M, van der Knaap WO, Lamentowicz M (2013) Palaeohydrology, fires and vegetation succession in the southern Baltic during the last 7500 years reconstructed from a raised bog based on multiproxy data. Palaeogeogr Palaeoclimatol Palaeoecol 370:209-221

Gałka M, Tobolski K, Zawisza E, Goslar T (2014) Postglacial history of vegetation, human activity and lake-level changes at Jezioro Linówek in northeast Poland, based on multi-proxy data. Veget Hist Archaeobot 23:123-152. doi:10.1007/s00334-013-0401-7

Gauthier E, Bichet V, Massa C, Petit C, Vannière B, Richard H (2010) Pollen and non-pollen palynomorph evidence of medieval farming activities in southwestern Greenland. Veget Hist Archaeobot 19:427-438

Giesecke T, Davis B, Brewer S et al (2014) Towards mapping the late Quaternary vegetation change of Europe. Veget Hist Archaeobot $23: 75-86$
Gładki M (2007) Chronologia schyłkowej fazy wczesnej epoki żelaza w mikroregionie jez. Salęt w świetle badań na stanowisku II w Wyszemborku, gm. Mrągowo, woj. warmińsko-mazurskie. In: Bitner-Wróblewska A (ed) Kultura bogaczewska w 20 lat później. Materiały z konferencji, Warszawa, 26-27 marca 2003. Seminarium Bałtyjskie vol. 1. Państwowe Muzeum Archeologiczne w Warszawie, Stowarzyszenie Naukowe Archeologów Polskich, Oddział w Warszawie, Warszawa, pp 25-39

Godłowski K (1974) Chronologia okresu późnorzymskiego i wczesnego okresu wędrówek ludów $w$ Polsce północno-wschodniej. Rocznik Białostocki 12:9-109

Grabowski R (2011) Changes in cereal cultivation during the Iron Age in southern Sweden: a compilation and interpretation of the archaeobotanical material. Veget Hist Archaeobot 20:479-494

Gręzak A, Piotrowska-Małecka J (2007) Animal bone remains from the Early Iron Age settlement in Jeziorko. In: Makohonienko M, Makowiecki D, Czerniawska J (eds) Eurasian perspectives on environmental archaeology. The 2007 AEA Annual Conference, September 12-15, 2007, Poznań, Poland. Bogucki Wydawnictwo Naukowe, Poznań, pp 163-166

Guiry MD, Guiry GM (2013) AlgaeBase. World-wide electronic publication, National University of Ireland, Galway. http://www. algaebase.org. Accessed 10 Dec 2013

Haug GH, Günther D, Peterson LC, Sigman DM, Hughen KA, Aeschlimann B (2003) Climate and the collapse of Maya civilization. Science 299:1,731-1,735

Heikkilä M, Seppä H (2010) Holocene climate dynamics in Latvia, eastern Baltic region: a pollen-based summer temperature reconstruction and regional comparison. Boreas 39:705-719

Heinsalu A, Veski S (2010) Palaeoecological evidence of agricultural activity and human impact on the environment at the ancient settlement centre of Keava, Estonia. Est J Earth Sci 59:80-89

Hoffmann MJ (2000) Kultura i osadnictwo południowo-wschodniej strefy nadbałtyckiej w I tysiacleciu p.n.e. Towarzystwo Naukowe i Ośrodek Badań Naukowych im. Wojciecha Kętrzyńskiego, Olsztyn

Holzhauser H, Magny M, Zumbühl HJ (2005) Glacier and lake-level variations in west-central Europe over the last 3500 years. Holocene 15:789-801

Hughes PDM, Mauquoy D, Barber KE, Langdon PG (2000) Mire development pathways and palaeoclimatic records from a full Holocene peat archive at Walton Moss, Cumbria, England. Holocene 10:465-479

Huntley B, Birks HJB (1983) An atlas of past and present pollen maps for Europe 0-13,000 years ago. Cambridge University Press, Cambridge

Iversen J (1973) The development of Denmark's nature since the Last Glacial. Reitzels Forlag, København

Jańczak J (1999) Atlas Jezior Polski, vol 3. IMGW, Bogucki Wydawnictwo Naukowe, Poznań

Jankovská V, Komárek J (2000) Indicative value of Pediastrum and other coccal green algae in palaeoecology. Folia Geobot 35:59-82

Karczewska M, Karczewski M (2002) Osada z okresu wpływów rzymskich i okresu wędrówek ludów w Paprotkach Kolonii stanowisko $41 \mathrm{w}$ Krainie Wielkich Jezior Mazurskich, vol 1. Badania archeologiczne, Podlasko-Mazurska Pracownia Archeologiczna, Białystok

Karczewska M, Karczewski M, Pirożnikow E (2002) Osada z okresu wpływów rzymskich i okresu wędrówek ludów w Paprotkach Kolonii stanowisko 41 w Krainie Wielkich Jezior Mazurskich, vol 2. Analizy paleoekologiczne, Podlasko-Mazurska Pracownia Archeologiczna, Białystok

Karczewski M (2011) Archeologia środowiska zachodniobałtyjskiego kręgu kulturowego na pojezierzach. Bogucki Wydawnictwo Naukowe, Poznań-Białystok 
Karczewski M (2012) Human impact on the landscape of Masurian Lakeland in the Roman Period (NE Poland). eTopoi J Ancient Stud 3:255-266

Karge W, Schmied H, Münch E (2000) Die Geschichte Mecklenburgs. Hinstorff, Rostock

Kausrud KL, Begon M, Ben Ari T, Viljugrein H, Esper J, Büntgen U, Leirs H, Junge C, Yang B, Yang M, Xu L, Stenseth NC (2010) Modeling the epidemiological history of plague in Central Asia: palaeoclimatic forcing on a disease system over the past millennium. BMC Biol 8:112-125

Koff T, Punning JM (2002) The last 100 years of land-use history in Estonia as inferred from pollen records. Ann Bot Fenn 39:213-224

Kondracki J (2011) Geografia regionalna Polski. PWN, Warszawa

Kowalski J (2000) Chronologia grupy elbląskiej i olsztyńskiej kręgu zachodniobałtyjskiego (V-VII w.). Zarys problematyki Barbaricum 6:203-266

Kożuchowski K (2011) Klimat Polski. Nowe spojrzenie, PWN, Warszawa

Kreuz A, Schäfer E (2008) Archaeobotanical considerations of the development of Pre-Roman Iron Age crop growing in the region of Hesse, Germany, and the question of agricultural production and consumption at hillfort sites and open settlements. Veget Hist Archaeobot 17:159-179

Kupryjanowicz M, Mueller-Bieniek A, Cywa K, Karczewski M (2013) Intensywna eksploatacja lasów przez ludność kultury bogaczewskiej: mikroregion osadniczy nad jeziorem Wons (Kraina Wielkich Jezior Mazurskich). In: Ciecierka $\mathrm{H}$, Hołdyński C (eds) Interdyscyplinarne i aplikacyjne znaczenie nauk botanicznych. Dziedzictwo przyrodnicze Warmii, Mazur i Powiśla. Przewodnik do warsztatów terenowych 56 Zjazdu PTB Olsztyn, 24-30 czerwca 2013. Oddział Olsztyński PTB, Olsztyn, pp 365-379

Lagerås P, Bartholin T (2003) Fire and stone clearance in Iron Age agriculture: new insights inferred from the analysis of terrestrial macroscopic charcoal in clearance cairns in Hamneda, southern Sweden. Veget Hist Archaeobot 12:83-92

Latałowa M (1999) Palaeoecological reconstruction of the environmental conditions and economy in early medieval Wolin against a background of the Holocene history of the landscape. Acta Palaeobot 39:183-271

Liedgren L (1992) Hus och gård i Hälsingland. En studie av agrar bebyggelse och bebyggelseutveckling i norra Hälsningland Kr.f 600 e.Kr. Studia Archaeologica Universitatis Umensis 2, Umeå

Lindbladh M, Niklasson M, Nilsson SG (2003) Long-time record of fire and open canopy in a high biodiversity forest in southeast Sweden. Biol Cons 114:231-243

Lityńska-Zając M (1997) Roślinność i gospodarka rolna w okresie rzymskim. Studium archeobotaniczne, Instytut Archeologii i Etnologii PAN, Kraków

Löwenborg D (2012) An Iron Age shock doctrine did the AD 536-537 event trigger large-scale social changes in the Mälaren valley area? J Archaeol Anc Hist 4:1-29

Madeja J, Wacnik A, Wypasek E, Chandran A, Stankiewicz E (2010) Integrated palynological and molecular analyses of late Holocene deposits from Lake Miłkowskie (NE Poland): verification of local human impact on environment. Quat Int 220:147-152

Matuszkiewicz W (2005) Przewodnik do oznaczania zbiorowisk roślinnych Polski. PWN, Warszawa

Matuszkiewicz JM (2008) Geobotanical regionalization of Poland. IGiPZ PAN, Warszawa

Medeanic S (2006) Freshwater algal palynomorph recordsfrom Holocene deposits in the coastal plain of Rio Grande do Sul, Brazil. Rev Palaeobot Palynol 141:83-101

Medeanic S, Jankovská V, Dillenburg SR (2003) The implication of green algae (Chlorophyta) for palaeoecological reconstruction of the Holocene lagoon system in the Tramandai Lagoon region, Rio Grande do Sul, Brazil. Acta Palaeobot 43:113-123

Montoya E, Rull V, van Geel B (2010) Non-pollen palynomorphs from surface sediments along an altitudinal transect of the Venezuelan Andes. Palaeogeogr Palaeoclimatol Palaeoecol 297:169-183

Müller-Wille M, Dörfler W, Meier D, Kroll H (1988) The transformation of rural society, economy and landscape during the first Millennium AD: archaeological and palaeobotanical contributions from Northern Germany and Southern Scandinavia. Geogr Ann 70:53-68

Nalepka D, Walanus A (2003) Data processing in pollen analysis. Acta Palaeobot 43:125-134

Niinemets E, Saarse L (2006) Holocene forest dynamics and human impact in southeastern Estonia. Veget Hist Archaeobot 16:1-13

Niinemets E, Saarse L (2007a) Mid- and late-Holocene land-use changes inferred from pollen records, in a south-eastern Estonian upland area. Rev Palaeobot Palynol 146:51-73

Niinemets E, Saarse L (2007b) Fine-resolution pollen-based evidences of farming and forest development, South-Eastern Estonia. Pol J Ecol 55:283-296

Nowakiewicz T, Nowakiewicz-Rzeszotarska A (2012) Lake Nidajno near Czaszkowo in Masuria: a unique sacrificial site from Late Antiquity. Komitet Nauk Pra- i Protohistorycznych Polskiej Akademii Nauk, Instytut Archeologii Uniwersytetu Warszawskiego, Instytut Archeologii i Etnologii Polskiej Akademii Nauk, Warszawa

Nowakowska M (2004) Pochówki zbiorowe na brukach kamiennych ze schyłku epoki brązu na cmentarzysku w Wyszemborku, gm. Mrągowo, stanowisko IVa. In: Hoffmann MJ, Sobieraj J (eds) Pruthenia Antiqua, Studia do Pradziejów i Wczesnej Historii Ziem Pruskich, vol. 1. Człowiek a środowisko w epoce brązu i wczesnej epoce żelaza u południowo-wschodnich pobrzeży Bałtyku. Stowarzyszenie Naukowe Archeologów Polskich Oddział w Olsztynie, Muzeum Warmii i Mazur w Olsztynie, Olsztyn, pp 329-337

Nowakowski W (1995) Od Galindai do Galinditae. Z badań nad pradziejami bałtyjskiego ludu z Pojezierza Mazurskiego. Barbaricum 4, Instytutu Archeologii UW, Warszawa

Nowakowski W (1996) Das Samland in der römischen Kaiserzeit und seine Verbindungen mit dem römischen Reich und der barbarischen Welt. Veröffentlichung des Vorgeschichtlichen Seminars Marburg 10. Marburg-Warszawa

Nowakowski W (2000) Die Balten zwischen Weichsel und Memel zwischen 400 und 800 n.Chr. Ein Entwurf der Forschungsproblematik, Archaeologia Baltica 4:9-25

Nowakowski W (2004) Bałtowie lud na końcu świata. In: Andrzejowski J, Kokowski A, Leiber C (eds) Wandalowie. Strażnicy bursztynowego szlaku. Katalog wystawy, Państwowe Muzeum Archeologiczne w Warszawie, 8 marca-16 czerwca 2004. Wydawnictwo Uniwersytetu Marii Curie-Skłodowskiej w Lublinie i Państwowego Muzeum Archeologiczne w Warszawie, Lublin-Warszawa, pp 253-262

Okulicz Ł (1970) Kultura kurhanów zachodniobałtyjskich we wczesnej epoce żelaza. Zakład Narodowy im, Ossolińskich, Wrocław-Warszawa-Kraków

Okulicz J (1973) Pradzieje ziem pruskich od późnego paleolitu do VII w. Zakład Narodowy im. Ossolińskich, Wrocław, n.e

Okulicz Ł (1976) Osadnictwo strefy wschodniobałtyckiej w I tysiącleciu przed naszą erą. Zakład Narodowy im, Ossolińskich, Wrocław-Warszawa-Kraków

Okulicz J (1981) Grupy mrągowska i węgorzewska kultury zachodniobałtyjskiej a zagadnienie "Galindai" i "Sudinoi" Ptolemeusza. Rocznik Białostocki 14:151-167

Okulicz J (1989) Kultura kurhanów zachodniobałtyjskich. In: Kmieciński J (ed) Pradzieje Ziem Polskich, Tom I od paleolitu 
do środkowego okresu lateńskiego, Część 2. Epoka brązu i początki epoki żelaza, PWN, Warszawa-Łódź, pp 584-603

Påhlsson I (1982) Cannabis sativa in Dalarna. Striae 14:79-82

Polcyn M (2000) Archaeobotanical finds from the West Baltic Barrow culture lake dwellings in Pieczarki (Great Masurian Lakeland). An attempt at the reconstruction of plant economy. In: Kola A (ed) Studies in Lake Dwellings of West Baltic Barrow Culture. Toruń, UMK, pp 101-190

Poska A, Saarse L, Veski S (2004) Reflections of pre- and earlyagrarian human impact in the pollen diagrams of Estonia. Palaeogeogr Palaeoclimatol Palaeoecol 209:37-50

Poska A, Sepp E, Veski S, Koppel K (2008) Using quantitative pollen-based land-cover estimations and a spatial CA_Markov model to reconstruct the development of cultural landscape at Rõuge, South Estonia. Veget Hist Archaeobot 17:527-541

Power MJ, Marlon J, Ortiz N et al (2008) Changes in fire regimes since the Last Glacial Maximum: an assessment based on a global synthesis and analysis of charcoal data. Clim Dyn 30:887-907

Punning J-M, Koff T, Ilomets M, Jõgi J (1995) The relative influence of local, extra-local, and regional factors on organic sedimentation in the Vällamäe kettle hole, Estonia. Boreas 24:65-80

Ralska-Jasiewiczowa M (1966) Bottom sediments of the Mikołajki Lake (Masurian Lake District) in the light of palaeobotanical investigations. Acta Palaeobot 7:1-118

Ralska-Jasiewiczowa M, Latałowa M (1996) Poland. In: Berglund BE, Birks HJB, Ralska-Jasiewiczowa M, Wright HE (eds) Palaeoecological events during the last 15000 years. Regional synthesis of palaeoecological studies of lakes and mires in Europe, Wiley, Chichester, pp 403-472

Ralska-Jasiewiczowa M, Wacnik A, Mamakowa K, Nalepka D (2004) Betula L Birch. In: Ralska-Jasiewiczowa M, Latałowa $M$, Wasylikowa K, Tobolski K, Madeyska E, Wright HE Jr, Turner Ch (eds) Late Glacial and Holocene history of vegetation in Poland based on isopollen maps W. Szafer Institute of Botany. Polish Academy of Sciences, Kraków, pp 56-68

Rasmussen P (2005) Mid- to late-Holocene land-use change and lake development at Dallund S $\varnothing$, Denmark: vegetation and land-use history inferred from pollen data. Holocene 15:1116-1129

Reimer PJ, Baillie MGL, Bard E et al (2009) IntCal09 and Marine09 radiocarbon age calibration curves, $0-50,000$ years cal. BP. Radiocarbon 51:1,111-1,150

Richling A, Ostaszewska K (2005) Geografia fizyczna Polski. PWN, Warszawa

Rösch M (2008) New aspects of agriculture and diet of the early medieval period in central Europe: waterlogged plant material from sites in south-western Germany. Veget Hist Archaeobot 17:225-238

Rösch M, Ehrmann O, Goldammer JG, Herrmann L, Page H, Schulz E, Hall M, Bogenrieder A, Schier W (2004) Slash-and-burn experiments to reconstruct Late Neolithic shifting cultivation. Int Forest Fire News 30:70-74

Rull V (2009) New paleoecological evidence for the potential role of fire in the Gran Sabana, Venezuelan Guayana, and implications for early human occupation. Veget Hist Archaeobot 18:219-224

Saarse L, Niinemets E, Poska A, Veski S (2010) Is there a relationship between crop farming and the Alnus decline in the eastern Baltic region? Veget Hist Archaeobot 19:17-28

Sarmaja-Korjonen K (2003) Contemporaneous Alnus decline and the beginning of Iron Age cultivation in pollen stratigraphies from southern Finland. Veget Hist Archaeobot 12:49-59

Sernander R (1908) On the evidences of post-glacial changes of climate furnished by the peat-mosses of Northern Europe. Geol Fören Förhandl 30:465-473

Sillasoo Ü, Mauquoy D, Blundell A, Charman D, Blaauw M, Daniell JRG, Toms P, Newberry J, Chambers FM, Karofeld E (2007)
Peat multi-proxy data from Männikjärve bog as indicators of Late Holocene climate changes in Estonia. Boreas 36:20-37

Sillasoo Ü, Poska A, Seppä H, Blaauw M, Chambers FM (2009) Linking past cultural developments to palaeoenvironmental changes in Estonia. Veget Hist Archaeobot 18:315-327

Simniškytė A, Stančikaite M, Kiselienè D (2003) Continuity and discontinuity in Juodonys archaeological complex. Muinasaja Teadus 13:267-286

Sjögren P, Arntzen JE (2013) Agricultural practices in Arctic Norway during the first millennium BC. Veget Hist Archaeobot 22:1-15

Stančikaitè M, Kisilienè D, Strimaitienè A (2004) Vegetation response to the climatic and human impact changes during the Late Glacial and Holocene: case study of the marginal area of Baltija Upland, NE Lithuania. Baltica 17:17-33

Stančikaitė M, Baltrūnas V, Sinkūnas P, Kisieliené D, Ostrauskas T (2006) Human response to the Holocene environmental changes in the Biržulis Lake region, NW Lithuania. Quat Int 150:113-129

Stančikaitė M, Kisielienè D, Mažeika J, Blaževičius P (2008) Environmental conditions and human interference during the 6th and 13th to 15th centuries $\mathrm{AD}$ at Vilnius Lower Castle, east Lithuania. Veget Hist Archaeobot 17:239-250

Stančikaite M, Bliujiene A, Kisieliene D, Mažeika J, Taraškevičius R, Messal S, Szwarczewski P, Kusiak J, Stakénienè R (2013) Population history and palaeoenvironment in the Skomantai archaeological site, West Lithuania: 2000 years. Quat Int 308-309:190-204

Stockmarr J (1971) Tablets with spores used in absolute pollen analysis. Pollen Spores 13:615-621

Swain AM (1973) A history of fire and vegetation in northeastern Minnesota as recorded in lake sediments. Quat Res 3:383-396

Święta-Musznicka J, Latałowa M, Badura M, Gołembnik A (2013) Combined pollen and macrofossil data as a source for reconstructing mosaic patterns of the early medieval urban habitats e a case study from Gdansk. N Poland J Archaeol Sci 40:637-648

Szafer W, Zarzycki K (1977) Szata roślinna Polski, tom II. PWN, Warszawa

Szymański P (2003) Wielokulturowa osada w Wyszemborku, stanowisko V, gm. Mrągowo. In: Wróblewski W (ed) Studia Galindzkie, vol 1. Warszawa, Zakład Archeologii Wczesnego Średniowiecza Instytutu Archeologii UW, pp 63-125

Szymański P (2005) Mikroregion osadniczy z okresu wpływów rzymskich w rejonie jeziora Salęt na Pojezierzu Mazurskim. Światowit Supplement Series P: Prehistory and Middle Ages, vol. 10. Instytutu Archeologii UW, Warszawa

Szymański P (2007) Stan badań nad osadami kultury bogaczewskiej. In: Bitner-Wróblewska A (ed) Kultura bogaczewska w 20 lat później. Materiały z konferencji, Warszawa, 26-27 marca 2003, Seminarium Bałtyjskie, vol. 1. Państwowe Muzeum Archeologiczne w Warszawie, Stowarzyszenie Naukowe Archeologów Polskich, Oddział w Warszawie, Warszawa, pp 167-187

Thurston T (2009) Unity and Diversity in the European Iron Age: out of the Mists, Some Clarity? J Archeol Res 17:347-423

Tinner W, Lotter AF, Ammann B, Conedera M, Hubschmid P, Van Leeuwen JFN, Wehrli M (2003) Climatic change and contemporaneous land-use phases north and south of the Alps 2300 BC to $800 \mathrm{AD}$. Quat Sci Rev 22:1,447-1,460

Tischler O (1885) Über Gliederung der La-Tène Periode und über die Dekorirung der Eisenwaffen in dieser Zeit. Korrespondenz-Blatt der deutschen Gesellschaft für Anthropologie. Ethnologie und Urgeschichte 16:157-161

Tischler O, Kemke H (1902) Ostpreussische Altertümer aus der Zeit der grossen Gräberfelder nach Christi Geburt. Königsberg

Tomanek J (1966) Botanika leśna. PWRiL, Warszawa

Turton CL, McAndrews JH (2006) Rotifer loricas in second millennium sediment of Crawford Lake, Ontario, Canada. Rev Palaeobot Palynol 141:1-6 
Uggla H (1969) Gleby gytiowe Pojezierza Mazurskiego, vol 1. Ogólna charakterystyka gleb gytiowo-bagiennych i gytiowomurszowych. Zesz Nauk WSR w Olsztynie 25:563-582

Uri V, Lohmus K, Tullus H (2003) Annual net nitrogen mineralization in a grey alder (Alnus incana (L.) Moench) plantation on abandoned agricultural land. For Ecol Manag 184:167-176

Van Geel B (1978) A palaeoecological study of Holocene peat bog sections in Germany and the Netherlands. Rev Palaeobot Palynol $25: 1-120$

Van Geel B (2001) Non-pollen palynomorphs. In: Smol JP, Birks HJB, Last WM (eds) Tracking environmental change using lake sediments (terrestrial, algal and silicaceous indicators), vol 3. Kluwer, Dordrecht, pp 99-119

Van Geel B, Andersen ST (1988) Fossil ascospores of the parasitic fungus Ustulina deusta in Eemian deposits in Danmark. Rev Palaeobot Palynol 56:89-93

Van Geel B, Aptroot A (2006) Fossil ascomycetes in Quaternary deposits. Nova Hedwigia 82:313-329

Van Geel B, Grenfell HR (1996) Spores of Zygnemataceae (Chapter 7A). In: Jansonius J, McGregor DC (eds) Palynology: principles and applications. Am Assoc Stratigr Palynol Found, Dallas, pp 173-179

Van Geel B, Bos J, Pals J (1983) Archaeological and palaeoecological aspects of a medieval house terp in a reclaimed raised bog area in north Holland. Ber Rijksd Oudheidk Bodemonderz 33:419-444

Van Geel B, Coope GR, van der Hammen T (1989) Palaeoecology and stratigraphy of the Lateglacial type section at Usselo (The Netherlands). Rev Palaeobot Palynol 60:25-129

Van Geel B, Mur LR, Ralska-Jasiewiczowa M, Goslar T (1994) Fossil akinetes of Aphanizomenon and Anabaena as indicators for medieval phosphate-eutrophication of Lake Gosciaz (Central Poland). Rev Palaeobot Palynol 83:97-105

Van Geel B, Raspopov OM, Renssen H, van der Pflicht J, Dergachev VA, Meijer HAJ (1999) The role of solar forcing upon climate change. Quat Sci Rev 18:331-338

Van Geel B, Buurman J, Brinkkemper O, Schelvis J, Aptroot A, van Reenena G, Hakbijl T (2003) Environmental reconstruction of a Roman Period settlement site in Uitgeest (The Netherlands), with special reference to coprophilous fungi. J Archaeol Sci 30:873-883

Veski S, Koppel K, Poska A (2005) Integrated palaeoecological and historical data in the service of fine-resolution land use and ecological change assessment during the last 1000 years in Rõuge, southern Estonia. J Biogeogr 32:1473-1488
Vuorela I (1973) Relative pollen rain around cultivated fields. Acta Bot Fenn 102:1-27

Wacnik A (2009) From foraging to farming in the Great Mazurian Lake District: palynological studies of Lake Miłkowskie sediments, North-East Poland. Veget Hist Archaeobot 18:187-203

Wacnik A, Karczewski M (2013) Przemiany roślinności a działalność społeczności rolniczych w rejonie Staświn na Pojezierzu Mazurskim (północno-wschodnia Polska). In: Ciecierka $\mathrm{H}$, Hołdyński C (eds) Interdyscyplinarne i aplikacyjne znaczenie nauk botanicznych. Dziedzictwo przyrodnicze Warmii, Mazur i Powiśla. Przewodnik do warsztatów terenowych 56 Zjazdu PTB Olsztyn, 24-30 czerwca 2013. Oddział Olsztyński PTB, Olsztyn, pp 351-364

Wacnik A, Ralska-Jasiewiczowa M, Madeyska E (2011) Late Glacial and Holocene history of vegetation in Gostynin area, central Poland. Acta Palaeobot 51:249-278

Wacnik A, Goslar T, Czernik J (2012) Late Holocene vegetation changes in the Great Mazurian Lake District and the activity of agricultural societies. The main stages of disturbances and the beginning of the large-scale deforestations. Acta Palaeobot 52:59-104

Walanus A, Nalepka D (2004) Integration of Late Glacial and Holocene pollen data from Poland. Ann Soc Geol Polon 74: 285-294

Woś A (1999) Klimat Polski. PWN, Warszawa

Wróblewski W (2006) Ziemie pruskie i jaćwieskie w okresie plemiennym (VII/VIII-XII/XIII wieku). In: Chudziak W, Moździoch S (eds) Stan i potrzeby badań nad wczesnym średniowieczem w Polsce -15 lat później. Toruń-WrocławWarszawa, pp 285-309

Wróblewski W, Nowakiewicz T, Bogucki M (2003) Terra desolata. Wczesnośredniowieczna Galindia w świetle badań mikroregionu Jeziora Salęt. In: Wróblewski W (ed) Studia Galindzkie I, Warszawa, pp 157-180

Zabłocki J (1950) Szczątki roślinne ze stanowiska wczesnośredniowiecznego w Jeziorku, pow. Giżycko, wydobyte w roku 1950. Materiały wczesnośredniowieczne 2:211-227

Zając A, Zając M (2001) Distribution atlas of vascular plants in Poland. Pracownia Chorologia Komputerowej Instytutu Botaniki Uniwersytetu Jagiellońskiego, Kraków

Zamaloa MC, Tell G (2005) The fossil record of freshwater microalgae Pediastrum Meyen (Chlorophyceae) in Southern South America. J Paleolimnol 34:433-444 